\title{
Met recht naar klimaatbescherming. Over de rol van het recht en de markt voor het klimaatbeleid
}

Citation for published version (APA):

Peeters, M. G. W. M. (2009). Met recht naar klimaatbescherming. Over de rol van het recht en de markt voor het klimaatbeleid. Europa Law Publishing. https://doi.org/10.26481/spe.20090213mp

Document status and date:

Published: 13/02/2009

DOI:

10.26481/spe.20090213mp

Document Version:

Publisher's PDF, also known as Version of record

\section{Please check the document version of this publication:}

- A submitted manuscript is the version of the article upon submission and before peer-review. There can be important differences between the submitted version and the official published version of record.

People interested in the research are advised to contact the author for the final version of the publication, or visit the DOI to the publisher's website.

- The final author version and the galley proof are versions of the publication after peer review.

- The final published version features the final layout of the paper including the volume, issue and page numbers.

Link to publication

\footnotetext{
General rights rights.

- You may freely distribute the URL identifying the publication in the public portal. please follow below link for the End User Agreement:

www.umlib.nl/taverne-license

Take down policy

If you believe that this document breaches copyright please contact us at:

repository@maastrichtuniversity.nl

providing details and we will investigate your claim.
}

Copyright and moral rights for the publications made accessible in the public portal are retained by the authors and/or other copyright owners and it is a condition of accessing publications that users recognise and abide by the legal requirements associated with these

- Users may download and print one copy of any publication from the public portal for the purpose of private study or research.

- You may not further distribute the material or use it for any profit-making activity or commercial gain

If the publication is distributed under the terms of Article $25 \mathrm{fa}$ of the Dutch Copyright Act, indicated by the "Taverne" license above, 


\section{Met Recht naar Klimaatbescherming}

Over de rol van het recht en de markt voor het klimaatbeleid 


\section{Colofon}

Design and print: Océ Business Services, Maastricht

ISBN:

NUR:

Alle rechten voorbehouden. Niets uit deze uitgave mag worden verveelvoudigd, opgeslagen in een geautomatiseerd gegevensbestand of openbaar gemaakt worden, zonder voorafgaande schriftelijke toestemming van de auteur of uitgever. 


\section{Met Recht naar Klimaatbescherming}

Over de rol van het recht en de markt voor het klimaatbeleid

\section{Prof. dr. Marjan Peeters}

Rede bij de aanvaarding van de leerstoel Milieubeleid en recht, in het bijzonder inzake klimaatverandering,

uitgesproken in verkorte vorm op vrijdag 13 februari 2009,

Universiteit Maastricht 
Met Recht naar Klimaatbescherming 


\section{Inhoudsopgave}

Over recht, handel, en grensoverschrijdende milieuproblemen $\quad 7$

Klimaatverandering en de noodzaak van overheidsinterventies 9

Met recht geen vrees voor de markt 23

Internationaal klimaatbeleid $\quad 27$

Europees en nationaal klimaatbeleid 43

$\begin{array}{ll}\text { Aanvullende benaderingen } & 61\end{array}$

$\begin{array}{ll}\text { Onderzoeksagenda } & 67\end{array}$

$\begin{array}{ll}\text { Slotwoord } & 73\end{array}$

$\begin{array}{ll}\text { Literatuur } & 77\end{array}$

Overige bronnen $\quad 88$

Jurisprudentie (inclusief administratief bezwaar / beroep) 93

Gerecht van Eerste Aanleg en Hof van Justitie EG 93

Nederland 93

Verenigd Koninkrijk $\quad 93$

Verenigde Staten 93 
Met Recht naar Klimaatbescherming 


\section{Over recht, handel, en grensoverschrijdende milieuproblemen}

1. Mijnheer de Rector Magnificus, zeer geachte toehoorders, graag neem ik u mee op een verkenning naar de waarde van het recht en de markt voor het klimaatbeleid.

De lucht en de zee, de vogels en de vissen kennen geen grenzen op aarde. Zij weten niet van het bestaan van een Europese Unie, een Verenigde Staten, Mexico, China of Madagaskar. Rivieren stromen dwars door continenten heen, oceanen beuken zonder onderscheid op allerlei kusten der aarde, en de atmosfeer verplaatst zich over immense afstanden. Natuur en natuurelementen bewegen vrijelijk over de aarde heen. ${ }^{1}$

2. Ondertussen heeft de mens op aarde systemen gecreëerd om het samenleven beheersbaar en aangenamer te maken. Het gaat om twee mechanismen, te weten de handel en het recht. Bij handel ruilen we schaarse goederen met elkaar. Het was Montesquieu die in 1748 schreef dat handel als vanzelf leidt naar vrede. ${ }^{2}$ Handel kan niet bestaan zonder afspraken, en daarmee zonder recht. Het recht heeft in onze democratische rechtstaat echter een ruimere betekenis dan slechts het faciliteren van privaatrechtelijke betrekkingen, aangezien het in brede zin overheidsoptreden legitimeert en controleert. In het EG-Verdrag en in onze Grondwet zijn bovendien sociale doelen geformuleerd die de overheid dient te behartigen. De bescherming van ons leefmilieu is een van deze taken. ${ }^{3}$

1 Deze aanhef is geïnspireerd door Jacques-Yves Cousteau, geciteerd door Richard Branson bij zijn toespraak tot de Verenigde Naties tijdens de bijeenkomst "Addressing Climate Change" op 11, 12 en 13 februari 2008, zie http://www.un.org/ga/president/62/ ThematicDebates/statements/RichardBransonSpeech.shtml.

2 Montesquieu, oorspronkelijke uitgave 1748, vertaling 2006, p 420. Hij relativeert deze stelling onmiddellijk: de geest van de handel moge volken bijeenbrengen, individuen worden er niet even sterk door verenigd.

3 Art. 21 van onze Grondwet, art. 2 en art. 174 EG-verdrag. Het EU-verdrag kent geen expliciete vermelding van het milieubelang. Het Verdrag van Lissabon kent enkele bepalingen over energie en klimaatverandering. Het Handvest van Grondrechten in de EU vermeldt het belang van een hoog niveau van milieubescherming in art. 37 . 
Een voorbeeld van door het recht ingestelde grenzen zijn staatsgrenzen. Zowel de handel als natuur en milieuverontreiniging is vaak landsgrensoverschrijdend van aard. In onze globaliserende wereld staat dan ook in het recht, en in het bijzonder ook in het milieurecht de internationale dimensie in toenemende mate centraal. 


\section{Klimaatverandering en de noodzaak van overheidsinterventies}

3. Een van de meest bedreigende milieuproblemen van deze tijd, en ook voor de toekomst, waarbij we kunnen denken aan ten minste de komende 100 jaar, is zo een grensoverschrijdend probleem. Het betreft het probleem van de klimaatverandering vanwege de opwarming van de aarde. Recent, in 2007, is door het 'Intergovernmental Panel on Climate Change' (IPCC) gesteld dat de mens met een geschatte kans van 90\% bijdraagt aan dit probleem. ${ }^{4}$ In terminologie van het IPCC is het voorts zeer waarschijnlijk dat de recente warme jaren toegeschreven kunnen worden aan menselijke activiteiten. Het gaat daarbij onder meer om de grootschalige verbranding van fossiele brandstoffen die begonnen is tijdens de Industriële Revolutie.5 Ook de broeikasgassen methaan en lachgas nemen toe door menselijke activiteiten. Daarnaast is de wijze van grondgebruik, waaronder grootschalige ontbossing, mede bepalend voor broeikasgasemissies. ${ }^{6}$ De met onzekerheden omgeven verwachting luidt dat aan het eind van deze eeuw een verdere opwarming zal hebben plaatsgevonden, tussen de 1,8 en 4 graden Celsius, alhoewel het om verschillende redenen niet mogelijk is om deze opwarming en met name ook de daaruit optredende effecten precies te voorspellen.7 Met name mogelijke extreme en snel optredende gebeurtenissen, zoals de vraag hoe de Noord-Atlantische Golfstroom zich zal gedragen en of deze plotseling van intensiteit zal veranderen, is omgeven met

4 Zie IPCC (2007), p. 39. Zie over klimaatveranderingen in het verleden en het feit dat nog veel onbekend is over hoe fauna en flora reageert op snelle klimaatverandering: Thijs Van Kolfschoten (2008).

5 Het IPCC gaat bij de beoordeling van de bijdrage van menselijke activiteiten aan klimaatverandering uit van 1750: IPCC (2007) p. 37.

6 Naast de opslag van $\mathrm{CO}_{2}$ door bossen, is ook de opslagcapaciteit van oceanen en landbodem van belang. Zie over de opslag door grond bijvoorbeeld recent: 'Submission by the United Nations Convention to Combat Desertification 4th Session of the Ad Hoc Working Group on Long-term Cooperative Action under the Convention (AWG-LCA 4)', Poznan, 1-10 December 2008, te vinden op http://www.unccd.int/publicinfo/poznanclimatetalks/docs/Submission_by_UNCCD_to_AWG-LCA_on_Biochar.pdf.

7 IPCC (2007) p. 45 en verder. De verwachte opwarming heeft betrekking op het eind van deze eeuw ten opzichte van eind vorige eeuw. Voor opwarming ten opzichte van de jaren 1850-1899 moet o,5 graden Celsius worden opgeteld (p. 45 Table 3.1 note d). 
grote onzekerheid. ${ }^{8}$ Bovendien is het gemakkelijker om de mondiale effecten te voorspellen, de grote trend dus, in plaats van de effecten die meer precies lokaal of regionaal zullen optreden. Ondertussen wordt voorts door Pier Vellinga, hoogleraar Klimaatverandering, water en veiligheid gesteld dat gelet op nieuwe wetenschappelijke bevindingen de situatie nog ernstiger is dan in het IPCC rapport is geprojecteerd. 9

De klimaatverandering kan volgens inschattingen tot dramatische effecten leiden. ${ }^{\circ} \mathrm{Ik}$ wil met klem benadrukken dat die effecten met name op andere plaatsen dan in Nederland kunnen optreden, en dus in armere landen dan de onze, waar men zich dan ook slechter of soms helemaal niet kan voorbereiden op negatieve en levensbedreigende effecten zoals voedsel- en watertekorten. Klimaatverandering kan natuurlijk ook wel positieve effecten hebben. Een mooie zomeravond in de herfst of lente met een goed glas wijn, mogelijk zelfs van druiven geteeld op Hollandse bodem, is waar velen zich goed bij voelen. Bovendien gloort in Groenland, waar de mensen onder moeilijke omgevingsomstandigheden leven, hoop op een onafhankelijk bestaan, onder meer omdat vanwege de opwarming het land en de delfstoffen beter bewerkbaar en winbaar zijn.

4. Het recht komt in beeld daar waar met name ernstige negatieve effecten kunnen ontstaan. De kernvraag is dan in hoeverre via het recht ernstige klimaatschade kan worden voorkomen dan wel in hoeverre eventuele toch nog optredende klimaatschade zal

8 Zie over sociaal-wetenschappelijke analyses van zo een scenario, met bijzondere aandacht voor Nederland: J.C.M. Van den Bergh, A.J. Dietz, C.J. Jepma, F. Langeweg (ed.) (2008). Bijzonder ook is te zien hoe snel de verwachtingen vanuit de natuurwetenschappelijke hoek aan verandering onderhevig zijn, gedurende de loop van dit NWO project zijn de inzichten over het kouder worden in Noord West Europa bijgesteld, zie kort daarover V. Bruggeman en M. Peeters in genoemde uitgave.

9 Pier Vellinga (2008).

10 Nicholas Stern - die een ruimschoots door de media verkondigd rapport heeft gepubliceerd - vergelijkt de gevolgen van klimaatverandering met de economische depressie in de jaren dertig en de wereldoorlogen van de vorige eeuw, Stern (2007) (executive summary) p. 2. 
moeten worden vergoed." Mijn onderzoek richt zich met name op de inzet van het recht als sturingsinstrument, met het oog op een reductie van broeikasgassen en een vergroting van het aandeel duurzame energie. De nadruk ligt daarbij op de totstandbrenging en toepassing van juridische instrumenten in ontwikkelde landen zoals in ons land en op het niveau van de Europese Unie. Het is dringend nodig te bezien hoe in deze ontwikkelde rechtssystemen invulling kan worden gegeven aan de verantwoordelijkheid van de huidige generatie om voor toekomstige generaties een goed klimaat na te laten. Gelet op de belangrijke aanwijzingen voor een door de mens veroorzaakte klimaatverandering ligt het in de rede om ons $\mathrm{nu}$ in te spannen om een redelijke reductie van broeikasgassen te realiseren. Er zijn dusdanige waarschuwingen voor een mogelijke invloed van de mens dat wij onze verantwoordelijkheid niet kunnen ontlopen om maatregelen te treffen ter afwending van het mogelijke gevaar, hetgeen in feite de essentie is van het in het milieurecht genestelde voorzorgsbeginsel, en het in het privaatrecht ontwikkelde gevaarzettingsbeginsel. In mijn onderzoek richt ik mij op de vraag hoe emissiereducties de komende tijd gerealiseerd kunnen worden, waarbij we kunnen denken aan een doelstelling van min $20 \%$ of min $30 \%$ in 2020 in vergelijking met het basisjaar 1990.

Inmiddels wordt de noodzaak van klimaatregelgeving ook in jurisprudentie erkend: in het voorjaar van 2007 heeft het Hooggerechtshof van de Verenigde Staten geoordeeld dat koolstofdioxide en andere broeikasgassen, tot dusver niet specifiek gereguleerd door de Amerikaanse Clean Air Act, als vervuilende stoffen moeten worden gezien in de zin van de deze wet hetgeen een bevoegdheid (en in feite een plicht) impliceert voor het Amerikaanse Federale Environmental Protection Agency (EPA) om daadwerkelijk

11 Intrigerend is voorts de analyse van Montesquieu in 1748 - dus nog voordat de menselijk veroorzaakte klimaatverandering werd besproken - dat wetten moeten overeenkomen met de fysieke omstandigheden van een land. Dit aspect valt buiten het onderwerp van deze rede, maar het is in het licht van de huidige klimaatverandering frappant om zijn (uiteraard later door anderen becommentarieerde) gedachten te lezen over de sterke verschillen in karakter en emoties al naargelang het klimaat verschilt, waarop naar zijn mening door wetten zou moeten worden aangesloten, zie Montesquieu, Boek XIV: 'Over de wetten in relatie tot het klimaat' (vertaling 2006). 
tot uitvoeringsregelgeving over te gaan. ${ }^{2}$ Deze gedachte dat er regelgeving zou moeten komen is onlangs nog behandeld door de beroepsinstantie van het EPA inzake de beslissing van een regionaal uitvoeringsorgaan van het EPA om aan een vergunning voor een afvalen koolcentrale geen voorschriften te verbinden voor $\mathrm{CO}_{2}$, aangezien daarvoor geen bevoegdheid zou bestaan.13 Het beroep ingesteld door de Sierra Club, een milieuorganisatie, slaagt in zoverre dat de zaak wordt terugverwezen voor heroverweging over de vraag of kooldioxide gelet op de specifieke wettelijke bepalingen van de Clean Air Act als een te reguleren stof moet worden gezien en of er in casu technische maatregelen voor $\mathrm{CO}_{2}$ kunnen worden opgelegd in de vergunning. Daarbij wordt door de beroepsinstantie meegegeven dat nader overwogen moet worden of een algemene regeling dienaangaande beter zou zijn dan $\mathrm{CO}_{2}$ emissies 'case by case' via vergunningverlening te regelen.14 De kernvraag voor de komende tijd is dan ook hoe de klimaatregelgeving er uit moet zien, en met welke intensiteit en fasering emissiereducties zullen worden afgedwongen.

5. We zullen overigens pas over 10 of 20 jaar zekerheid hebben dat de recente warmere jaren toegeschreven kunnen worden aan invloeden van de mens. Nanne Weber, bijzonder hoogleraar klimaatmodellering en klimaatanalyse, heeft aangegeven dat klimaatonderzoekers de stelling dat de mens een rol speelt in de recente warme jaren graag voorzichtiger formuleren. De reden daarvoor is dat als de gebruikte modelmatige benadering bepaalde factoren een klein beetje overschat, het verhaal er anders uit komt te zien. ${ }^{15}$ Ook worden nog steeds nieuwe ontdekkingen gedaan; zo is begin 2009 bericht over het feit dat in afsmeltend ijs op Antarctica ijzerdeeltjes aanwezig zijn die algengroei bevorderen, hetgeen tot een extra opname van $\mathrm{CO} 2$ door oceanen zou leiden. ${ }^{16}$

12 Supreme Court USA, Massachusetts v Environmental Protection Agency 549 U.S. 497 (2007) (uitspraak van 2 april 2007). Zie hierover Jeffrey A. Smith (2007), Marjan Peeters (2007C). Het EPA is in 2008 overigens nog niet tot regelgeving overgegaan.

13 Het federale EPA is in casu bevoegd voor vergunningverlening voor de kolencentrale aangezien deze in een Indianenreservaat zou worden gevestigd.

14 The Environmental Appeals Board, United States Environmental Protection Agency, Washington D.C., in re Deseret Power Electric Cooperative (November 13, 2008).

15 Nanne Weber (2008) p. 7.

16 Der Spiegel (2009), zie over het stimuleren van algengroei teneinde $\mathrm{CO}_{2}$ opname te bevorderen Rob Fowler (2008). 
Het bestaan van onzekerheden die onvermijdelijk een rol spelen bij de natuurwetenschappelijke voorspellingen, met name vanwege het feit dat met modellen nog niet precies te voorspellen is wat er gaat gebeuren met het klimaat op aarde, is een van de redenen waarom ik het idee om nu in definitieve termen over te gaan tot nationale emissiereductieverplichtingen voor een tijdstip ver gelegen van hier, te weten met name voor het jaar 2050, niet meteen omarm. Dit idee bloeit op verschillende plaatsen op. In GrootBrittannië is in november 2008 een wet aangenomen, de Climate Change Act 2008, met een emissiereductie van $80 \%$ in 2050 ten opzichte van 1990.17 Het idee is ook voorgesteld door Nederlandse milieuorganisaties in de vorm van een Klimaatwet waarin bindende doelstellingen zouden worden vastgelegd, waarbij in 2050 een reductie van $90 \%$ zou moeten zijn gerealiseerd. ${ }^{18}$ Dergelijke lange termijn doelstellingen worden overigens ook reeds in de literatuur bepleit. ${ }^{9}$ In mijn opvatting, echter, is er alle aanleiding om voor kortere termijnen, zoals voor 2020 of wellicht 2030 afspraken te maken, maar liggen 2040 en 2050 nog wel erg ver in de ongewisse toekomst. Gelet op de onzekerheden lijkt het verstandig om eerst bijvoorbeeld per decennium vast te stellen wat precies, in termen van (internationale en) wettelijke verplichtingen, zal moeten worden gedaan. Bovendien moeten we niet de neiging hebben na ons graf te regeren: elke generatie zou zelf moeten mogen vaststellen, ook aan de hand van de dan geldende inzichten, welke emissiereductie zal worden ondernomen..$^{\circ}$ De Britse Climate Change Act bevat in deze een interessante benadering: de emissiereductiedoelstelling van $80 \%$ in 2050 wordt in de wet vastgesteld, doch daaraan is meteen verknoopt dat de desbetreffende verantwoordelijke minister een aanpassing mag voorstellen als dat op grond van natuurwetenschappelijke ontwikkelingen of ontwikkelingen

17 Zie voor informatie over deze wet: http://www.defra.gov.uk/environment/climatechange/uk/legislation/docs.htm. De wet is inmiddels van kracht geworden.

18 Zie de website http://www.klimaatwet.nu/home, en het Ontwerp voor een Klimaatwet (http://www.klimaatwet.nu/downloads/ontwerp_wettekst.pdf), en de memorie van toelichting op dit voorstel (http://www.klimaatwet.nu/downloads/toelichting_op_ ontwerpwettekst.pdf).

Andri Wibisana (2008). 
van internationaal en Europees recht aangewezen zou zijn. ${ }^{21}$ Een economische crisis is overigens niet in de wet als versoepelingsgrond genoemd. De minister dient bij het voorstel tot aanpassing van de emissiereductiedoelstelling rekening te houden met het advies van het bij dezelfde wet ingestelde Klimaatcomité. Ik denk dat een dergelijk mechanisme, waarin enerzijds een lange termijn doelstelling wordt aangegeven, maar waarbij tegelijkertijd een procedure wordt vastgesteld voor besluitvorming over de vraag of de doelstelling nog houdbaar is, met daarbij een adviserend comité, een goed voorbeeld is van hoe kan worden omgegaan met de onderhavige problematiek. Juist bij problemen die worden omgeven met onzekerheid is immers een met waarborgen omgeven mogelijkheid tot herziening van gekozen voorzorgsdoelstellingen nodig.22 Het blijft van belang de ontwikkeling van natuurkundige en andere wetenschappelijke inzichten te volgen en aan de hand daarvan van tijd tot tijd opnieuw de vraag te stellen wat passende reductiedoelstellingen zijn. Juist inherent aan het nemen van voorzorg is om van tijd tot tijd te ijken of de inschattingen nog steeds op dezelfde wijze aangehouden moeten worden, dan wel of de voorzorg naar boven of beneden moet worden bijgesteld. ${ }^{23}$ Dit inzicht over de betekenis van het voorzorgsbeginsel is bij mij ontstaan door samen te werken in het onderzoek dat aan deze Universiteit wordt verricht over onzekere risico's onder leiding van Marjolein van Asselt en Ellen Vos.24 Ik zou dan ook bij de eventuele en op zich ook naar mijn oordeel gewenste totstandkoming van een Nederlandse Klimaatwet, of bij de opstelling van wellicht lange termijn klimaatdoelstellingen op EU niveau willen aanbevelen uitdrukkelijk naar deze Britse herzieningsclausule inzake de emissiereductiedoelstelling voor 2050 te kijken. Interessante onderzoeksvragen zijn met name hoe de status en onafhankelijkheid van het adviserend Comité luidt, hoe het parlement haar controle op

21 Climate Change Act 2008, Part 1 par. 1. Zie over de moeilijke afdwingbaarheid van dergelijke wettelijke emissiereductiedoelstellingen Peter McMaster (2008) die een ontwerp voor de Britse klimaatwet bespreekt.

22 Dit is een van de inzichten gegenereerd tijdens het STEM onderzoek naar onzekere risico's, zie Dave Huitema, Nicole Niessen, Marjan Peeters (2006).

23 Zie een argumentatie voor een dergelijke graduele benadering ook in Martin L. Weitzman (2007), m.n. p 722-723. Jaap Spier (2008, p. 2525) benadrukt dat men onder ogen moet zien dat de inzichten steeds veranderen en dat er steeds meer reden is voor uitzonderlijk grote zorg. Uiteraard kan het ook zo zijn dat bepaalde zorg later niet of minder nodig blijkt te zijn. 
de regering uitoefent, en, uiteraard, op kracht van welke argumenten en nieuwe inzichten voorzorgsmaatregelen worden geïntensiveerd of versoepeld.

6. Voor de klimaatwetgever is het bovendien bijzonder moeilijk dat een van de grootste onzekerheden niet zo zeer natuurwetenschappelijk maar maatschappelijk van aard is: het is erg onvoorspelbaar hoe de maatschappij en de economie zich gaan ontwikkelen, hoeveel broeikasgassen dientengevolge worden uitgestoten, en wat de kosten zullen zijn van reducties. ${ }^{25}$ De in het najaar van 2008 ontstane kredietcrisis, die overging in een recessie, is een voorbeeld van zo een onvoorspelbare toekomst. In de literatuur wordt niettemin getracht om binnen deze onzekerheid uitspraken te doen over de vraag langs welk gradueel pad de emissiereducties moeten worden aangebracht: het gaat hier om de kernvraag hoe scherp het beleid nu moet zijn en hoe scherp het beleid bijvoorbeeld in 2025, 2035 of 2040 zou moeten zijn, en welke variant haalbaar en bovendien de meest optimale keuze zou zijn. ${ }^{26}$ Het in 2006 uitgekomen Sternrapport, dat in de media grote aandacht heeft gekregen vanwege de stelling dat op korte termijn scherpe emissiereducties moeten worden doorgevoerd, omdat zulks goedkoper zou zijn dan actie

25 Nanne Weber stelde in haar presentatie voor de vergadering van de Vereniging van Milieurecht inzake Klimaatverandering en rechtsontwikkeling anno 2008, Utrecht, 26 november 2008 dat qua onzekerheden te denken valt aan financiële crises, economische bloei, oorlogen, et cetera.

26 Verschillende auteurs stellen op grond van modelberekeningen dat een emissiereductie van $50 \%$ in 2050 op zich gewoon mogelijk is, zowel technologisch als economisch Deze berekeningen zijn gemaakt voordat de financiële crisis in 2008 - met mogelijke doch nog niet volledig duidelijke gevolgen voor de reële economie - ontstond: Jim Skea, Jim, Shuzo Nishioka (2008), 58. Zie ook OECD (2008) "Tackling global environmental impacts in the next decades would cost just over 1 per cent of the world's gross domestic product"; Zie ook Stern (2007) executive summary, p. xi, stellend dat een effectief klimaatbeleid economische groei niet hoeft te hinderen, maar zie ook de kritiek op de conclusies van Stern. Zie in het verlengde van Stern het Committee on Climate Change UK (2008) over de doelstelling van $-80 \%$ in 2050: "The costs to the UK from this level of emissions reduction can be made affordable - we estimate between 1-2\% of GDP in 2050 - with appropriate policies and trajectories. Our estimates are the same order of magnitude as those provided by the Stern Review and other estimates for global emissions reductions". Echter, een rapport van het Internationaal Energieagentschap waarschuwt dat het niet met zekerheid te voorspellen is of de technologische vereiste veranderingen inderdaad haalbaar zijn "Even leaving aside any debate about the political feasibility of the 450 Policy Scenario, it is uncertain whether the scale of the transformation envisaged is even technically achievable, as the scenario assumes broad deployment of technologies that have not yet been proven": http://www.iea.org/Textbase/npsum/WEO2008SUM.pdf. 
later in de toekomst, is onder meer sterk bekritiseerd door de economen Nordhaus en Weitzman. ${ }^{27}$ Behalve fikse methodische kritiek, waaronder dat door Stern onvoldoende wordt duidelijk gemaakt dat hij extreme en in de economische theorie niet erg gangbare uitgangspunten heeft gekozen, wordt door met name Nordhaus gesteld dat het Stern-rapport een erg politiek karakter heeft, ter ondersteuning van het beleid van de op dat moment in functie zijnde premier Blairr. ${ }^{28}$ Ook hiermee wordt aangetoond, dat het vaststellen van het klimaatbeleid met waarborgen moet worden omgeven. Juist vanwege de onzekerheden is er ruimte om het onbekende dusdanig in te vullen dat dit beter bij een (mogelijk korte termijn) politieke ambitie past, dan dat sprake is van de keuze voor een optimale variant. Hier zijn het met name de staatsrechtjuristen die aan de slag moeten om na te denken over procedures en instrumenten om tot een zo integer en optimaal mogelijk omgaan met klimaatonzekerheid te bevorderen. De benadering om gekozen doelstellingen van tijd tot tijd te herijken, via een transparant proces, is derhalve niet alleen nodig vanwege onzekerheid over de natuur, onzekerheid over de ontwikkeling van de maatschappij, en onzekerheid of technologische en andere aanpassingen kunnen worden doorgevoerd, maar ook vanwege het politieke karakter van de besluitvorming en, zoals gezegd, het ook voorkomende politieke karakter van adviserende rapporten. Dat politieke karakter kan leiden tot mogelijk te scherpe, maar waarschijnlijk veelal ook te lage doelstellingen, aangezien de besluitvorming onder sterke druk staat van degenen die belang hebben bij het instandhouden van bestaande structuren. Het klimaatbeleid zal dus in het teken moeten staan van een debat en uitwisseling van argumenten over de intensiteit van de maatregelen, en bij dat debat hoort een kritische opstelling over adviserende rapporten, en zelfs ook over die afkomstig van het IPCC panel. Volgens het klassieke beginsel

27 William D. Nordhaus, (2007); Martin L. Weitzman (2007). Zie ook Lawrence Solomon, auteur van het boek "The Deniers" (2008) (waarbij Solomon onder meer kritiek op het IPCC door Richard Tol interpreteert; uiteraard moeten voor een goede beschouwing de geschriften van Tol zelf bezien worden).

William D. Nordhaus (2007) p. 688: "...the Review should be read primarily as a document that is political in nature and has advocacy as its purpose". Nordhaus stelt zelfs dat de door Stern voorgestelde strategie voor de toekomst eventueel ook slechter kan uitpakken (p. 695), en dat het nemen van snelle actie inefficiënt zou zijn. Zie ook Weitzman, p. 723. Zie over de kritiek op het gebrek aan communicatie over de extreme veronderstellingen Weitzman p. 724. 
van hoor en wederhoor dienen tegengeluiden serieus te worden genomen, juist om tot zo goed mogelijke inzichten te komen.

7. Als we dus nu voor de kortere termijn, op basis van beschikbare inzichten, uitgaan van een emissiereductiedoelstelling van bijvoorbeeld 20 of 30 procent in 2020, zoals ook in de EU is besloten in december 2008, dan is de kernvraag op welke wijze dit kan worden bereikt en welke functie wetgeving hierin kan vervullen. Dat overheidsingrijpen kan verschillende vormen aannemen. ${ }^{29}$ Echter, zo gauw de overheid complexe processen wil gaan sturen, en het streven naar substantieel minder broeikasgassen is daar een voorbeeld van, ontstaat de vraag of de overheid dat eigenlijk wel zo goed kan..$^{30}$ In zijn algemeenheid wordt nog steeds en terecht stevig kritiek uitgeoefend op het nut van en de werking van overheidsinterventies en geldt in het wetgevingsbeleid dan ook dat we nog op zoek zijn naar kwaliteit. ${ }^{31}$ Dit betreft zowel onze nationale wetgeving, als ook het ingrijpen op het niveau van de EU. Terzake een van de centrale milieurichtlijnen, de zogenoemde IPPC-richtlijn, die een hoog niveau van bescherming van het milieu in zijn geheel beoogt te verwezenlijken door integrale vergunningverlening, heeft Eberhard Bohne op basis van een indrukwekkende studie verzucht dat de richtlijn eigenlijk net zo goed achterwege had kunnen blijven. ${ }^{22}$ Bovendien hebben Michael Faure en Jürgen Lefevere laten zien dat deze richtlijn sterk kan worden bekritiseerd vanwege het gebruik van het criterium van de beste beschikbare technieken.33 Terzake een andere Europese richtlijn, de richtlijn milieuaansprakelijkheid, heeft onze collega Kristel de Smedt laten zien dat vanuit rechtseconomisch perspectief eigenlijk geen goede argumenten zijn ter rechtvaardiging van deze richtlijn. ${ }^{34}$ Deze voorbeelden waarschuwen ons dat regelgeving op EU-niveau niet per definitie optimale keuzes zijn. Anderzijds

29 Zie ook het als zodanig globale overzicht gegeven door IPCC (2007) p. 61.

30 Zie de oraties van Frans L. Leeuw (2008) en Rob van Gestel (2008).

31 L.F.M. Verhey (red.) (2003). Op EU niveau zijn initiatieven aangekondigd ter verbetering van de kwaliteit van de wetgeving (better regulation), doch de werkelijke verbetering behoeft de aandacht van wetenschappelijk onderzoek. European Commission (2001), European Governance, A White Paper, COM(2001) 428 final, Brussels, 25.7.2001, p. 20.

34 Kristel De Smedt (2007). 
wint de Europese regelgeving vooral aan betekenis vanwege het stellen van milieukwaliteitsdoelstellingen en vanwege het in het EG-verdrag neergelegde handhavingsmechanisme waardoor de lidstaten uiteindelijk door het Hof van Justitie veroordeeld kunnen worden indien de gestelde milieudoelen (en andere milieunormen) niet worden gehaald.

Overigens is de naleving door lidstaten een zorgpunt.35 Ook Nederland heeft geen schone lei waar het gaat om het nakomen van Europese milieuverplichtingen. Inderdaad, ook in een ontwikkelde maatschappij als de onze is het nog steeds welhaast aan de orde van de dag dat onafhankelijke onderzoekers en adviesraden, zoals de Algemene Rekenkamer, de VROM-raad, en natuurlijk ook de wetenschap tekortschietend optreden aan de orde stellen. Op Europees niveau zien we dat het milieubeleid het terrein is waarop de meeste ingebrekestellingen worden uitgevaardigd door de Europese Commissie en veroordelingen door het Hof van Justitie worden uitgesproken. ${ }^{6}$ Een voorbeeld: ingevolge de in 1996 aangenomen richtlijn inzake geïntegreerde preventie en bestrijding van verontreiniging (de zojuist reeds vermelde IPPC-richtlijn) dienden grote industriële bedrijven per 30 oktober 2007 (dus ruim tien jaar na dato vaststellen richtlijn) over een vergunning te beschikken in overeenstemming met deze richtlijn. Op de implementatiedatum van 30 oktober 2007 voldeed volgens opgave van de Nederlandse regering circa $80 \%$ van de vergunningen aan de richtlijn. Nederland is dan ook met acht andere lidstaten in gebreke gesteld. ${ }^{37}$ Een ander bekend voorbeeld waar de voor 2010 gestelde doelen niet worden behaald is de luchtkwaliteitsproblematiek: recent werd bekend dat met name de limiet voor NOx naar verwachting door 13 lidstaten waaronder Nederland - niet wordt behaald.$^{38}$

8. Ondertussen wordt een steeds groter appèl gedaan op de overheid om te interveniëren, ook onder invloed van de documentaire 'An

35 De naleving door lidstaten wordt jaarlijks gerapporteerd, zie Commission of the European Communities (2008a).

36 Ludwig Krämer (2006).

37 Brief van de Minister van Volkshuisvesting, Ruimtelijke Ordening en Milieubeheer, Den Haag, 24 september 2008, Kamerstukken II, 22 343, nr. 22.

38 Europees milieuagentschap (2008a). Als reden wordt aangegeven het groeiend transport. 
Inconvenient Truth' en het feit dat aan de maker van deze documentaire zowel een Nobelprijs als een Oscar is toegekend. Hoe ongemakkelijk is overigens de waarheid dat in dezelfde week dat de Nobelprijs werd toegekend, een Engelse rechter, de High Court of Justice te Londen, heeft geoordeeld dat deze documentaire negen onjuistheden bevat.39 Dit leidde tot een rechterlijk bevel dat de documentaire niet zonder begeleidende informatie mag worden getoond in de openbare lagere scholen van het Verenigd Koninkrijk. We zien hier dat het recht dus ook alreeds een functie kan vervullen waar het gaat om verspreiding van en inhoud van klimaatinformatie en de bescherming van schoolgaande kinderen tegen onjuiste informatie.40 Ondertussen is de klimaatverandering voor de burger maar ook voor de wetenschapper moeilijk in zijn volle omvang te bevatten: de problematiek is gigantisch, want wereldwijd, en is zeer complex van aard, met nog vele onzekerheden. ${ }^{4}$ Nieuwe inzichten en voorspellingen voor het klimaat aan het eind van de eeuw rollen over elkaar heen. De ontwikkeling naar een maatschappij die niet meer zo zwaar afhankelijk is van fossiele brandstoffen is een gigantische omwenteling, en het vergt dus ook dat ons denken over oplossingsrichtingen om zowel de reductie van broeikasgassen te bewerkstelligen als ons te beschermen tegen negatieve effecten baanbrekend zal moeten zijn. Het recht zal hier een modificerende rol moeten vervullen, te weten het faciliteren en sturen van verandering. ${ }^{42}$ Ondanks de vele vragen rondom overheidssturing zal toch met kennis en inzicht van een zeker moment tot bepaalde interventies moeten worden overgegaan. Juristen moeten daarbij niet in bestaande systemen blijven denken, maar waar nodig creatief en scheppend zijn, om in de woorden van mijn vroegere leermeester Schoordijk te spreken. ${ }^{43}$

39 Judgment of the High Court of Justice, Queen's Bench Division, Administrative Court, Case No: CO/3615/2007, date 10/10/2007 (mr Justice Burton).

40 Vergelijk ook de analyse van Brenninkmeijer dat er tegenkrachten nodig zijn bij mediavoorzieningen, met zijn suggestie voor een mediaombudsman: Brenninkmeyer (2008). Zie over de taak van de overheid inzake informatieverschaffing bij onzekere klimaatverandering Véronique Bruggeman en Marjan Peeters (2008).

41 Farhana Yanamin en Joanne Depledge hebben terecht opgemerkt dat het onmogelijk is voor een enkel persoon om het internationale klimaatregime zoals neergelegd in het klimaatverdrag en het Kyoto Protocol te overzien en te begrijpen, Farhana Yanamin, Joanna Depledge (2004).

42 T. Koopmans (1970).

43 H.C.F. Schoordijk (2008). 
9. Vanuit de literatuur wordt er naar mijn mening terecht op gewezen dat snelle actie niet per se goede actie is; er is tijd nodig om een geschikt juridisch sturingsinstrument, met bijbehorend uitvoeringsen handhavingsapparaat, te ontwikkelen.44 Tegelijkertijd moeten we beseffen dat een eenzijdige blik op terugbrenging van broeikasgasemissies tot onwenselijke effecten kan leiden op andere terreinen, zoals een beïnvloeding van de voedselprijs. Zoals alle milieujuristen weten is een van de belangrijke uitgangspunten in het milieurecht dat maatregelen integraal moeten worden bezien. Al sinds de jaren tachtig wordt in het milieurecht, met name ook door mijn dierbare promotor wijlen Piet Gilhuis, gepleit voor integrale afwegingen, omdat het sturen op een afgezonderd milieu-item kan betekenen dat er ergens anders een milieulast ontstaat.45 Dergelijke verschuivingen kunnen zich ook op grote schaal voordoen in het kader van het klimaatbeleid: een eenzijdige belasting van fossiele energie kan leiden tot een grotere inzet van nucleaire energie. ${ }^{46}$ Het feit dat integrale afwegingen moeilijk te maken zijn betekent niet dat het belang van een integrale afweging niet zou moeten worden onderkend. Art. 6 van het EG-verdrag schrijft bovendien voor dat "de eisen inzake milieubescherming moeten worden geïntegreerd in de omschrijving en uitvoering van het beleid en het optreden van de Gemeenschap" en dat dit in het bijzonder dient te gebeuren met het oog op het bevorderen van een duurzame ontwikkeling. We duiden dit integratiebeginsel met externe integratie, daarmee bedoelend dat het milieubelang meegewogen moet worden in andere beleidsterreinen zoals landbouw en transport. Echter, we zien in het klimaatbeleid, dat juist de effecten van klimaatmaatregelen voor andere beleidsterreinen moet worden afgewogen. In het klimaatbeleid doet zich dus het interessante fenomeen voor dat we het externe integratiebeginsel

44 Cary Coglianese (2008), eerder M. Zinn (2007).

45 Overigens is het doen van integrale afwegingen complex en kent daardoor wellicht ook grenzen. Daarnaast wordt uit oogpunt van een controle van het bestuur een te vergaande integratie bekritiseerd. Gilhuis pleitte overigens genuanceerd voor integratie, en vroeg aandacht voor het overdenken van nut ervan om niet te belanden in een willekeurig integratieproces, zie J.M. Verschuuren (2006) m.n. p. 2 en p. 14. Zie verder over de problemen bij het bepalen van een ecologische voetprint voor activiteiten, hetgeen waarlijk een integrale benadering zou zijn: Opschoor (2000).

46 Zie voor een Nederlands voorbeeld: Kamerstukken II 2006/7, 31 028, nr. 1 over de evaluatie van de MEP subsidie en de tekortkomende samenhang met ander beleidsdoelen op het gebied van duurzaamheid en $\mathrm{CO}_{2}$ reductie. 
als het ware omgekeerd moeten toepassen, in die zin dat ook moet worden nagegaan of een klimaatmaatregel (de milieumaatregel dus) niet tot ongewenste sociaal-economische neveneffecten leidt. We zien dit op het terrein van de biobrandstoffen: een sterke stimulans van deze biobrandstoffen omdat dit de benutting van fossiele energie zou verminderen kan ongewenste effecten hebben op andere milieuonderdelen zoals lucht en water maar ook op de voedselvoorziening. Aangezien de landbouwproducten voor energie en niet voor voedsel worden gebruikt, kan immers een stijging van de voedselprijzen ontstaan. Een van de uitgangspunten van het klimaatbeleid moet dan ook zijn dat een forse en dus ingrijpende maatregel die ziet op de terugbrenging van fossiele brandstoffen moet worden bezien op mogelijke ongewenste sociaaleconomische neveneffecten, waarbij dan kan worden nagegaan hoe die ongewenste effecten kunnen worden voorkomen dan wel kunnen worden verzacht. 47

Deze omgekeerde toepassing van het beginsel van externe integratie (dus nagaan of een milieumaatregel niet tot ongewenste sociaaleconomische neveneffecten leidt) is in het bijzonder belangrijk vanwege de grote voorkeur voor marktconforme instrumenten, die naar hun aard eenzijdig zijn in tegenstelling tot de integrale afweging zoals die in de Wet milieubeheer en in de IPPC-richtlijn worden voorgeschreven. ${ }^{8}$ Aangezien de belangrijkste beslissingen bij marktconforme regulering op macroniveau, dus op wetgevingsniveau worden genomen, moeten mogelijke neveneffecten daar expliciet aan de orde worden gesteld en worden afgewogen. Tegelijkertijd kan de integrale afweging ook tot zeer positieve uitkomsten leiden: de reductie van fossiele brandstoffen heeft immers ook een verbetering van de algemene luchtkwaliteit tot voordeel.49 Het recht, in het

47 De richtlijn hernieuwbare energie, waarover in december overeenstemming is bereikt tussen het Europees parlement en de Raad, kent inmiddels criteria voor duurzame biobrandstoffen, met een rapportageplicht voor de Europese Commissie inzake de neveneffecten. Uiteraard zal de effectiviteit van deze maatregel moeten worden geëvalueerd. Inzake neveneffecten is altijd nog waardevol te zien hoe Bressers in zijn studie heeft gewezen op het optreden van dergelijke effecten bij bepaalde ingrepen, in casu de heffing: J.Th. Bressers (1983).

48 Overigens is het de vraag hoe werkelijk integraal deze afwegingen zijn. Zie Frans Oosterhuis, Marjan Peeters en Rosa Uylenburg (2007), maar ook Eberhard Bohne (2006). 
bijzonder het integratiebeginsel dat moet doorklinken in dewetgeving en de daarop gebaseerde bestuurlijke besluitvormingsprocedures, heeft een belangrijke rol te vervullen voor het bevorderen van een evenwichtige besluitvorming, ook om mogelijke neveneffecten van klimaatvriendelijke oplossingen in kaart te krijgen. Enkele voorbeelden van klimaatmaatregelen waarbij negatieve effecten in ogenschouw moeten worden genomen zijn: windmolens, warmtekoude opslag, ${ }^{\circ}$ het onder de grond opslaan van kooldioxidegas, en, zoals gezegd, het gebruik van biobrandstoffen. ${ }^{11}$

10. De overheid staat voor de lastige taak om binnen afzienbare tijd keuzes te maken inzake het niveau van broeikasgasreducties op de korte en lange termijn, en om instrumenten te ontwerpen en te implementeren voor het verwezenlijken van deze reducties. In het milieurecht hebben we een dergelijke opgave nog niet eerder gezien, en we staan anno 2009 in feite nog maar aan het begin van de ontwikkeling van het klimaatbeleid en het klimaatrecht.

50 Zie in dat verband over de vergunningplicht en het beschermingskader voor warmte / koude opslag ABRvS 26 maart 2008, Tijdschrift voor Milieu en Recht, 2008, jur.nr. 60, met annotatie door Marleen van Rijswick.

51 Marjan Peeters (2009a). 


\section{Met recht geen vrees voor de markt}

11. Over de wijze waarop de overheid in het klimaatbeleid zou moeten sturen lijkt in de kern overeenstemming te bestaan: in vele studies wordt gesteld dat de overheid op de een of andere manier de emissie van broeikasgassen financieel zou moeten belasten..$^{22}$ Daarbij wordt zelfs al gesproken over een wereldwijde koolstofbelasting die voor een langere termijn zou moeten gelden. ${ }^{3}$ Het IPCC projecteert reeds mogelijke prijzen per ton $\mathrm{CO}_{2}$ voor het jaar 2030, maar daar zit nog een groot verschil tussen minimum prijs (20 euro per ton $\mathrm{CO}_{2}$ equivalent) en maximum prijs (80 euro per ton $\mathrm{CO}_{2}$-equivalent), te weten een verschil van 60 euro per ton. 54

12. Kenmerkend aan het klimaatbeleid is dus dat zowel in de literatuur als in de beleidspraktijk het marktconforme instrumentarium, in het bijzonder het zogenaamde instrument van broeikasgasemissiehandel, een hoofdrol speelt. Met dit beleidsinstrument roept de overheid bewust een kunstmatige markt in het leven, in feite een broeikasgasemissierechtenmarkt, om op die manier op een kosteneffectieve manier reducties van broeikasgassen te bereiken. Het instrument is in essentie eenvoudig. Het houdt in dat voor een maximale hoeveelheid milieubelasting door de overheid emissierechten worden uitgegeven. Zonder een dergelijk recht mogen de milieuvervuilende stoffen, in casu broeikasgassen, niet uitgestoten worden. De rechten zijn verhandelbaar, en daarmee ontstaat marktwerking: bedrijven die goedkoop emissies kunnen reduceren zullen onder invloed van de prijs van de emissierechten

52 Zie Nicholas Stern (2007) executive summary p. 1 en xviii, daarbij verwijzend naar een wereldwijde koolstofprijs. Zie bijvoorbeeld ook Jim Skea, Shuzo Nishioka (2008) p.11, Neil Strachan, Tim Foxon, Junichi Fujino (2008) p. 28. Zie voor een kritische benadering specifiek over emissiehandel Robert Baldwin (2008).

53 Neil Strachan, Tim Foxon, Junichi Fujino (2008) p. 28.

54 IPCC (2007), p. 60-61: "An effective carbon-price signal could realise significant mitigation potential in all sectors. Modelling studies show that global carbon prices rising to US\$2O-80/tCO2-eq by 2030 are consistent with stabilisation at around $550 \mathrm{ppm} \mathrm{CO}_{2}$-eq by 2100 . For the same stabilisation level, studies since the TAR that take into account induced technological change may lower these price ranges to US\$5-65/tCO2-eq in 2030." Voor de emissierechtenprijs in Europa is een schatting gemaakt van tussen de 20 en 50 euro per ton $\mathrm{CO}_{2}$, maar uiteraard is dit afhankelijk van vele factoren. Tweede Kamer, vergaderjaar 2007-2008, 31 362, nr. 36, p. 2. 
zelf maatregelen nemen, terwijl bedrijven waarbij de kosten voor reductie hoog zijn rechten zullen kopen ter compensatie van die uitstoot. De economische literatuur bepleit deze vorm van regulering al sinds de jaren zestig van de vorige eeuw, ook voor de regulering van andere vormen van luchtvervuiling, en voor behoud van waterkwaliteit en natuurbescherming. De kerndoelstelling is dat een gewenste milieukwaliteit wordt bereikt tegen lage kosten. .55

13. Het model van een 'global carbon market', een wereldwijde koolstofmarkt,dieals vanzelfs prekend zal doorwerken in het dagelijkse handelen van bedrijven, burgers en overheden is daarbij een welhaast utopisch idee. Voorlopig ligt zo een internationale koolstofmarkt die alle bronnen zou omvatten buiten bereik, aangezien het bijna niet voorstelbaar is dat er een internationale afspraak zou komen tussen ontwikkelde en ontwikkelingslanden over een eensluidende aanpak. Wel zijn er belangrijke aanzetten voor regionale koolstofmarkten, waarmee we in een interessante pioniersfase zijn beland voor de nadere verkenning van de vormgeving en de effecten van dergelijke koolstofmarkten.

Niettemin zien we in de literatuur een aanzet tot de gedachte dat de nationale klimaatwetgeving in een land in feite één koolstofmarkt zou moeten realiseren. Jonathan B. Wiener heeft in een recente publicatie betoogd dat in de VS een wet zou moeten worden vastgesteld waarbij alle broeikasgassen, sectoren, bronnen en opslagmogelijkheden van $\mathrm{CO}_{2}$ zouden moeten worden ondergebracht. ${ }^{6}$ De Britse Climate Change Act is niet zo vergaand als het voorstel van Wiener, maar gaat in de richting van dat idee.

14. Maar eigenlijk weten we nog te weinig over de mogelijkheden van de via juridische maatregelen gecreëerde vormen van marktwerking. Er is wel een zeer positief resultaat bereikt met de toepassing van emissiehandel op ander gebied, maar dit betekent niet dat het instrument daarmee ook automatisch een succes zou zijn op het terrein van klimaatverandering. ${ }^{57}$ Dat maakt dat we ons de vraag moeten stellen hoe op het terrein van klimaatverandering zo een

55 Zie over het instrument Marjan Peeters (1992). Zie ook Reinske Teuben (2005).

56 Jonathan B. Wiener (2008).

57 Rock Pring (2006). 
broeikasgasmarkt er uit zou kunnen zien, en hoe de overheid een dergelijke koolstofmarkt zou kunnen bestieren.

15. Inmiddels is het nog prille internationale en Europese klimaatbeleid alreeds gestoeld op een marktconforme aanpak via de verhandelbare vervuilingsrechten. Echter, het economische instrument van handel in vervuilingsrechten wordt met name door juristen nogal eens onwennig benaderd. $5^{8}$ Vanuit onze achtergrond en opleiding zijn wij, met name de publiekrechtelijk georiënteerde juristen, waarschijnlijk meer vertrouwd met directere vormen van regulering, met name in de vorm van gedragsvoorschriften. Voor een goed begrip van het instrument zullen we dan ook als juristen kennis moeten nemen van de literatuur van die andere discipline, de economische. Deze literatuur is dusdanig overtuigend over de voordelen van het instrument dat wij als juristen geen vrees moeten hebben voor toepassing ervan, maar juist mee moeten denken over een zo goed mogelijke vormgeving en toepassing, en met economen mee moeten denken over de vraag wanneer en hoe toepassing geschikt is. Voor sommige onderwerpen zullen klassieke voorschriften of, bij zeer ernstige risico's, een algemeen verbod de beste keuze zijn, en voor andere gevallen kunnen economische sturingsinstrumenten een betere keuze zijn. Bovendien is juist de juridische bestudering van economische instrumenten zoals een vergunningenmarkt van grote waarde: het instrument kan immers alleen maar via juridische instrumenten worden vormgegeven, en de toepassing van het instrument zal moeten voldoen aan het hele pakket van juridische randvoorwaarden. Vanuit het recht is immers de vraag hoe in lijn met rechtsbeginselen zoals gelijkheid en rechtszekerheid, maar ook in lijn met milieubeginselen, zoals het beginsel de vervuiler betaalt en het beginsel aan de bestrijding van de bron, het systeem kan worden vormgegeven. Een bijzonder aandachtspunt betreft de handhaafbaarheid van het systeem: juist doordat er een prijs wordt gezet op de broeikasgasemissies, is er een prikkel voor normontduikend gedrag. De controleerbaarheid en handhaafbaarheid van het systeem moet derhalve waterdicht zijn. Dat laatste is een reden om zeer kritisch te zijn over toepassing

58 Voorts geeft onze Algemene wet bestuursrecht (nog) geen regime voor het instrument van verhandelbare vergunningen; F. Van Ommeren (2004). We kunnen stellen, zoals al zo vaak is geweest, dat het milieurecht weer een belangrijke proeftuin is van nieuwe ontwikkelingen, in dit geval de verhandelbare rechten. 
van het instrument in rechtssystemen waar de handhaving nog onvoldoende ontwikkeld is, en waar ruimte bestaat voor fraude en corruptie.59 In die zin is het bijzonder om te zien dat het ingewikkelde en fraudegevoelige instrument van de verhandelbare rechten al wordt toegepast op internationaal niveau, aangezien de handhaving van normen over grenzen heen nog in opbouw is. In een eerdere publicatie heb ik vragen gesteld bij de waterdichtheid van het Europese broeikasgasemissiehandelssysteem. ${ }^{60}$ In feite zien we dat in de EU met dit marktconforme instrumentarium gestart is waarbij de waarborgen voor naleving onvoldoende verzekerd zijn. Dit is een uiterst kwetsbaar punt van het huidige beleid.

16. Het marktconforme karakter van het klimaatrecht moet bovendien goed worden doordacht gelet op de financiële crisis die in het najaar van 2008 is losgebroken. Deze financiële crisis illustreert dat er toezicht nodig is juist om een markt zo te laten werken dat dit maatschappelijk gewenst is. Het gaat daarbij om zowel overheidstoezicht en privaat toezicht, en om overheidstoezicht op dat privaat toezicht. In een beschouwing over de financiële crisis in relatie tot broeikasgasemissiehandel heeft Nicholas A. Robinson van Pace University School of Law, New York, en 'founding father' van de IUCN Academy of Environmental Law, laten zien hoezeer juist ook de rol, of een gebrekkige rol, van de overheid en van private toezichthouders mede debet is aan de financiële crisis. ${ }^{61}$ Het gaat hier uitdrukkelijk ook om accountants die onvoldoende de risico's van financiële ondernemingen hebben blootgelegd. Naast een "market failure", een imperfect werkende markt, kunnen we in dit geval ook spreken van een "government failure", een imperfect werkende overheid, en van tekortschietend privaatrechtelijk toezicht. Ook in dat laatste geval is het uiteindelijk de overheid die zou moeten ingrijpen om dergelijke falend privaatrechtelijk toezicht te voorkomen en, indien het wel plaatsvindt, nader aan te pakken.

59 Zo zijn deze instrumenten minder geschikt voor landen waar het rechtssysteem minder sterk ontwikkeld is, zie Michael Faure, Marjan Peeters en Andri Wibisana (2005).

60 Marjan Peeters (2006b).

61 N. Robinson (2008). 


\section{Internationaal klimaatbeleid}

17. Graag neem ik $u$ voor het vervolg van mijn rede mee naar enkele kernvragen omtrent het internationale en Europese klimaatbeleid. Hoe is het internationale klimaatbeleid nu tot op heden vormgegeven, en welke perspectieven zijn er voor een effectief internationaal klimaatbeleid? Studies wijzen uit dat het nemen van maatregelen in de ontwikkelde landen niet genoeg zal zijn. Juist in opkomende economieën zoals Brazilië, Mexico, Rusland, India en China is actie noodzakelijk. ${ }^{62}$ Aangezien broeikasgassen wereldwijd worden uitgestoten staan we voor de enorme opgave om tot een mondiale samenwerking te komen inzake de terugbrenging van broeikasgassen. Een zeer moeilijk te verwezenlijken doel daarbij is om een rechtvaardige verdeling te bereiken van de broeikasgasemissieruimte.

18. Een verdelingscriterium dat het meest het rechtvaardigheidsgevoel aanspreekt is het 'per capita' criterium: elke burger heeft evenveel recht op gebruikmaking van de broeikasgasemissieruimte, een "equal right to ecospace", waarbij we de atmosfeer zien als een gemeenschappelijk bezit, een 'global common'.63 De verdeling van emissiereductieafspraken tussen landen zou op dit per capita criterium kunnen worden gebaseerd. ${ }^{64}$

19. Hier in Nederland bedraagt de broeikasgasuitstoot per hoofd van de bevolking 12.7 ton koolstofdioxide-equivalenten, gemeten in 2006.65 Indien we uitgaan van een wereldbevolking van ruim 9 miljard in

62 OECD (2008).

63 Het zijn juist de ontwikkelingslanden, zoals India, die op het per capita criterium wijzen. Zie over het toegroeien naar een beperking van broeikasgassen uitgaande van een per capita verdeling het Global Commons Institue, http://www.gci.org.uk/, (waaronder de $\mathrm{GCl}$ Briefing Contraction and Convergence). Zie verder ook Marjan Peeters (2008b) par. 2.

64 Zie de kritiek van J.G. Lammers op E. Brown Weiss die stelt dat alle mensen een gelijke aanspraak hebben op het milieu. Dit is moeilijk inpasbaar in het volkenrecht dat zich op het gedrag van staten richt. J.G. Lammers (2007), p. 5. De per capita gedachte zou wel als grondslag kunnen dienen voor het vaststellen van statelijke verplichtingen. Zie verder ook Edward Page (2006).

65 Zoals becijferd voor 2006, zie de rapportage over Nederland zoals gepubliceerd door het Europese milieu-agentschap (2008b) ("Netherlands country profile"). 
2050 dan zou de gemiddelde acceptabele per capita uitstoot liggen rond de 2.4 ton per hoofd van de bevolking, ongeveer 20 procent van de huidige gemiddelde uitstoot per Nederlander. ${ }^{66}$ De totale uitstoot in Nederland in 2006 bedroeg 207,5 Mt. De uitstoot conform de Kyoto-norm moet in Nederland uiteindelijk naar 200,3 Mt ton kooldioxide-equivalenten, maar dat is slechts een eerste bescheiden stap. In de rijke landen woont 15 procent van de wereldbevolking, maar wordt 45 procent van de $\mathrm{CO}_{2}$ uitstoot veroorzaakt. De arme landen veroorzaken met eenderde van de wereldbevolking slechts 7 procent van de broeikasgasemissies. ${ }^{67}$

Het op het per capita criterium gebaseerde "Contraction and Convergence" model voorziet een geleidelijke vermindering en herverdeling van de broeikasgasruimte. Het verhandelen van de broeikasgasruimte is in dit model eveneens voorzien. Landen die meer broeikasgassen nodig hebben kunnen deze ruimte kopen van landen die een overschot hebben. Het zijn in principe de rijke landen die dan van de armere landen ruimte zouden kopen.

20. Het per capita criterium is in 2005 per amendement voorgesteld in onze Tweede Kamer maar helaas niet aangenomen. ${ }^{68}$ In de literatuur krijgt het idee steun ${ }^{69}$, maar worden ook alternatieve modellen ontwikkeld om een praktisch haalbare verdeling van de wereldwijde emissieruimte vorm te geven. ${ }^{\circ}$ Daarbij wordt bijvoorbeeld ook gekeken naar het vermogen om de klimaatkosten te betalen ('ability to pay' en het Bruto Nationaal Product per capita).

66 Het Britse Committee on Climate Change stelt een gemiddelde van 2.1 tot 2.6 ton per capita: Committee on Climate Change (2008).

67 United Nations Development Programme (2007), p. 42.

68 Zie het voorstel van kamerlid D. Samsom, TK 2004-2005, 28 240, no. 22, 15 maart 2005, (verworpen: Tweede Kamer Stemmingen 22 maart 2005, 62-3995).

69 F. Biermann (2005), p. 283; J.T. Houghton, (2004), p. 262. Edward A. Page (2006); zie verder het "contraction and convergence" model van de Global Commons Institute, www.gci.org.uk. Zie ook kort het idee om per capita als drempel te gebruiken voor het aangaan van emissiereductieverplichtingen: Jeffrey Frankel (2007) p. 42.

70 Zie bijvoorbeeld M.G.J. Den Elzen et. al (2004); Axel Michaelowa (2007), met literatuurreferenties; . Zie verder ook Joyeeta Gupta (2006), (2007) waar zij het door haar ontworpen KISS model uitlegt. 
Bovendien kan het per capita criterium niet zonder nuance worden gebruikt. In de eerste plaats is de waarde nauw gerelateerd aan de economische status van een land. De minst ontwikkelde landen hebben een lage per capita emissie, maar hebben tevens een zeer lage levensstandaard. ${ }^{\prime \prime}$ Een ander belangrijk criterium is derhalve de uitstoot van broeikasgassen per Bruto Nationaal product. Nederland zit wat dat criterium betreft hoger dan het gemiddelde en heeft dus meer emissies per Bruto Nationaal Product dan het gemiddelde van de EU-15, maar lager dan het gemiddelde van de EU-27.72 Ook is van belang dat in China de energie-intensiteit fors is afgenomen, hetgeen minder broeikasgasuitstoot betekent per eenheid BNP.73

Voorts moet bezien worden hoe de per capita emissie wordt berekend: is dit alleen de directe uitstoot in een land, of wordt de broeikasgasuitstoot van geïmporteerde producten zoals staal en elektriciteit, waarvoor de emissie dus elders is ontstaan, meegerekend? ${ }^{74}$ Het Kyoto Protocol gaat uit van de binnenlandse productie van emissies, maar het zou een realistischer beeld geven indien de totale consumptie wordt beschouwd, waarbij dus zowel de directe emissies als indirecte emissies van benutte goederen

71 In rapportages, zoals van het Europees milieubureau, wordt daarom ook de broeikasgasemissie per BNP uitgedrukt. Zie enkele waarschuwingen over deze benadering Ahnad (2004) p. 134. Economieën met lage (arbeids) kosten voor diensten krijgen bij dezelfde uitstoot als in economieën met hoge arbeids) kosten een slechter cijfer voor broeikasgasintensiteit.

72 Nederland: 388,3 GHG/GDP, EU 15: 381,7 GHG/GDP, en EU 27 442,5 GHG/GDP. Zie Europees milieuagentschap (2008). GHG staat voor greenhouse gas (broeikasgas) en GDP staat voor Gross Domestic Product (Binnenlands Bruto Product).

73 Global Carbon Project, http://www.globalcarbonproject.org/carbontrends/index.htm.: "After decades of improvements, the carbon intensity of the global economy, the carbon emitted per unit of Gross Domestic Product (GDP), was stalled during the period 2003-2005. This change was largely caused by China's rapidly growing share in economic output and carbon emissions. Since 2005 China's energy intensity (which underpins carbon intensity) has decreased (improved) by $1.2 \%$ in 2006 and $3.7 \%$ in 2007 compared to 2005 levels (according to the National Energy Administration in China.".

Nadim Ahmad (2004), p. 129. 
worden meegenomen.75 In de rijke landen (de OESO landen) heeft een overgang plaatsgevonden van industrie naar diensten, waarbij producten afkomstig van industrie worden geïmporteerd uit minder ontwikkelde landen. Het probleem echter is dat de totale consumptie van broeikasgassen vooralsnog moeilijk te berekenen is. Een voorzichtige schatting wijst er op dat in 1995 de consumptie van broeikasgassen door OESO landen $5 \%$ hoger was dan de productie van gassen binnen deze landen. ${ }^{6}$ Dit geeft een belangrijke indicatie dat een focus op productie van broeikasgassen een vertekend beeld geeft van de daadwerkelijke consumptie van deze gassen door de burgers van dat land.

21. Als we de broeikasgasuitstoot vertalen naar het aantal inwoners per land, dan krijgen weeen ander beeld dan als we de broeikasgasuitstoot als absoluut gegeven per land nemen. Zo is er in 2008 de aandacht op gevestigd dat China qua uitstoot de VS is voorbijgestreefd, maar als dit absolute uitstootcijfer van een land wordt gedeeld door het aantal inwoners dan wordt duidelijk dat de Amerikaanse burger zo een vijf keer meer uitstoot dan de Chinese burger.77 Bovendien is de energie-intensiteit verbeterd in China, en wordt een aanzienlijk deel van de in China vervaardigde producten waarbij broeikasgassen worden veroorzaakt, geconsumeerd in de EU en de VS. $7^{7}$ Als we voorts niet in absolute termen zouden zeggen welk land momenteel de grootste vervuiler is (gelet op de totale uitstoot van dat land in 2008 of 2009), maar welk land gemeten vanaf 1900 tot 2080 de

75 Ahmad maakt onderscheid tussen binnenlandse consumptie (inclusief de som van export en import) en binnenlandse productie (waarop Kyoto is gebaseerd). Nadim Ahmad (2004). Ahmad geeft voorts aan dat zijn analyse nog niet kan dienen voor het ontwikkelen van specifieke beleidsinstrumenten, wel voor een beter begrip van de oorzaken van broeikasgasemissies (p. 130). Navraag bij het Europees milieubureau heeft verduidelijkt dat bij de per capita getallen zoals zojuist voor Nederland genoemd alleen de binnenlandse emissies worden meegeteld, emissies afkomstig van geïmporteerde producten, waaronder elektriciteit, en van internationaal zee en luchttransport worden niet meegerekend. Zie verder over voor en tegens van een op consumptie gebaseerde telling van broeikasgasemissies Tao Wang en Jim Watson (2008) p. 582-583.

76 Nadim Ahmad, Andrew Wyckoff (2003).

77 Zie ook J.G. Lammers (2007) p. 37.

78 http://www.globalcarbonproject.org/carbontrends/index.htm (21; zie ook Botzen e.a. (2008) p. 574. 
grootste emittent zou zijn, dan wordt het land China pas tegen het midden van deze eeuw de grootste vervuiler.79

22. Politiek gezien is een per capita benadering of de verdere ontwikkeling daarvan vooralsnog een gevoelig onderwerp, omdat het model zou impliceren dat de meeste kosten bij de industriële wereld liggen en via de weg van de internationale emissiehandel een aanzienlijke stroom geld van rijk naar arm zou gaan. ${ }^{\circ 0}$ Niet alle industriële landen zijn zover om dit model te omarmen en er is geen supranationale autoriteit die dat kan opleggen. Bovendien moeten we de consequenties goed doordenken, en de vraag stellen hoe het per capita criterium zou kunnen worden geoperationaliseerd. Is het bijvoorbeeld eerlijk om burgers die in koude landen leven een zelfde emissieruimte toe te kennen in vergelijking met degenen die in een gematigd klimaat leven, waar minder energiegebruik nodig is? Lammers heeft er in zijn afscheidsrede als hoogleraar internationaal milieurecht echter in basale zin op gewezen dat zolang er grote verschillen zijn tussen de uitstoot per burger tussen de rijke landen en de arme landen moeilijk een coöperatievere rol van ontwikkelingslanden kan worden verwacht. ${ }^{81}$

Verschillende ontwikkelingslanden hameren op het belang van een rechtvaardige aanpak, waaronder het per capita criterium. Voor hen telt met name groei en niet klimaatbescherming, en dat is begrijpelijk. Tijdens een internationaal klimaatrechtcongres vorig jaar is door de milieujuristen uit de ontwikkelingslanden nog eens helder gesteld dat er andere problemen zijn die bij hen prioriteit hebben..$^{82}$

79 W.J.W Botzen e.a. (2008). Het door het Global Carbon Project samengestelde Carbon Budget 2007 bevat de volgende gegegens: From a historical perspective, developing countries with $80 \%$ of the world's population still account for only $20 \%$ of the cumulative emissions since 1751; the poorest countries in the world, with 800 million people, have contributed less than $1 \%$ of these cumulative emissions. http://www.globalcarbonproject.org/carbontrends/index.htm (21 oktober 2008).

80 Milieu en Natuur Planbureau (2007), Samenvatting xv, 2007.

81 J.G. Lammers (2007).

82 Zie voor dit congres en de uitgebrachte papers www.iucnael.org (website IUCN Academy of Environmental Law); in 2009 verschijnt bij Edward Elgar een verzameling van op het congres uitgebrachte papers. 
23. Terzake de Europese Unie zijn er overigens aanwijzingen dat het per capita criterium een belangrijkere rol zou kunnen gaan vervullen; in politieke zin is reeds door Nicolas Sarkozy en Angela Merkel in een gezamenlijke verklaring kort verwezen naar het per capita criterium:

"The international climate regime should be based on legitimate principles of equity, such as long-term convergence of emission levels per capita in the various countries." ${ }^{3}$

Wat mij betreft mag het criterium, of misschien wel beginsel, een stevigere juridische verankering krijgen, als een van de factoren voor het afspreken van klimaatverplichtingen tussen landen. Het Klimaatverdrag refereert in de preambule tot op heden slechts in algemene bewoordingen aan de per capita uitstoot en erkent in dat verband dat het aandeel in de broeikasgasruimte door ontwikkelingslanden zal toenemen:

"Vaststellende dat het grootste deel van de emissies van broeikasgassen over de gehele wereld, zowel in het verleden als in het heden, afkomstig is uit ontwikkelde landen, dat in ontwikkelingslanden de emissies per hoofd van de bevolking nog betrekkelijk gering zijn en dat het deel van de totale emissies dat afkomstig is uit ontwikkelingslanden zal toenemen naarmate wordt voorzien in hun behoeften van sociale aard en op het gebied van de ontwikkeling,"

Het per capita criterium en de daarin besloten consequentie van groei van ontwikkelingslanden is mijns inziens een belangrijk richtsnoer voor de lange termijn afspraken op wereldniveau. Het beginsel doet denken aan het bredere concept van de ecologische voetafdruk, dat een integrale benadering zou betreffen van de vraag in hoeverre door menselijk gedrag wordt bijgedragen aan de belasting van de aarde. Nader onderzoek heeft mij echter geleerd hoe complex dat ideële beginsel is. ${ }^{84}$ De literatuur wijst er op dat de berekening van deze voetafdruk incompleet is en dat de manier

83 Ninth Franco-German Council of Ministers - Joint statement by M. Nicolas Sarkozy, President of the Republic, and Mrs Angela Merkel, Chancellor of Germany, on the climate, 9 Juni 2008, http://www.ambafrance-uk.org/Franco-German-Council-ofMinisters,10729.html\#sommaire_2.

84 Marjan Peeters (2008b). 
waarop de variabelen zijn uitgewerkt te wensen over laat.85 Het zou dus mooi zijn als we eenvoudige en tot de verbeelding criteria zouden kunnen gebruiken, zoals het per capita criterium en de voetafdruk, maar we moeten daarbij ons wel blijven afvragen hoe dat dan kan en welke aanpalende criteria nodig zijn.

24. Ondertussen is er weinig voortgang te bespeuren in de onderhandelingen die zouden moeten leiden tot een effectieve internationale afspraak over broeikasgasreducties. In werkelijkheid is er een lastig politiek onderhandelingsproces over de verdeling van de emissieruimte. Dat onderhandelingsproces vindt overwegend plaats binnen het kader van het Klimaatverdrag. De kracht van dit in 1992 totstandgekomen Klimaatverdrag van de Verenigde Naties, waarvan meer dan 190 landen verdragspartij zijn, zit niet in concrete klimaatmaatregelen, maar in het consensuele besluitvormingsproces dat op basis van dit verdrag kan plaatsvinden. De verdragspartijen zijn verenigd in de Conferentie van de partijen, het hoogste besluitvormingsorgaanopgrondvan hetverdrag. ${ }^{86} \mathrm{Het} \mathrm{Klimaatverdrag}$ biedt voorts een kader voor verantwoording van de partijen ten opzichte van elkaar, via een mechanisme van rapportages en debat. Tijdens de jaarlijkse vergaderingen kan dan aan elkaar worden uitgelegd op welke wijze het nationale beleid wordt vormgegeven, en wat daarvan de verwachte en werkelijk gerealiseerde resultaten zijn. Wij juristen moeten niet de fout begaan door het internationale debat te snel te willen juridificeren door gefixeerd te zijn op concrete afspraken en sancties. Het proces van onderhandeling, het vaststellen van gemeenschappelijke uitgangspunten en van wat in realistische termen voor iedere verdragspartij de mogelijkheden zijn om aan de beheersing en vermindering van broeikasgassen bij te dragen is wat eerst serieus aandacht behoeft. ${ }^{87}$ Bijvoorbeeld op het als zodanige andere terrein van de grensoverschrijdende rivierbescherming is het besef gegroeid dat er een ingewikkeld conglomeraat van belangen en oplossingsrichtingen is waarbinnen - via een proces

85 Vromraad (1999), Hans Opschoor (2000); zie verder meer recent over beperkingen van de ecologische voetafdruk als sturingsinstrument voor de overheid Aaron Best e.a. 2008.

86 Zie art. 7 van het Klimaatverdrag. Interessant is dat de mogelijkheid wordt geboden om niet van unanieme besluitvorming maar tot andere stemmenmeerderheden over te gaan, art. 7(3) Klimaatverdrag.

87 Zie hierover A. Chayes en A.H. Chayes (1995), met dank aan Michael Faure voor zijn college hieromtrent. 
van onderhandeling - op een gegeven moment overeenstemming moet worden bereikt voor de bescherming van en gebruikmaking van het riviersysteem. Natuurlijk is het zo dat dit proces niet tot het optimale resultaat leidt, maar dat is ook moeilijk te bereiken bij een besluitvormingskader dat uitgaat van soevereine staten. ${ }^{88}$ Op immens grotere schaal is dat ook de reële situatie waarbinnen klimaatafspraken tot stand komen. Zo is gesteld over het Kyoto Protocol dat de daarin opgenomen afspraken over emissiereducties geen goede vertaling zijn van de historische verantwoordelijkheid van de ontwikkelde landen. De emissie-reductieverplichtingen die in 2008-2012 moeten worden nagekomen, ook door ons land, zijn - in nachtelijke onderhandelingsuren- tamelijk arbitrair tot stand gekomen. ${ }^{89}$ Voor een goed begrip van het het internationale klimaatbeleid zullen we een realistische en pragmatische benadering moeten aanhouden, en ons moeten beseffen dat een fundamenteel uitgangspunt zoals een per capita benadering al snel schade kan ondervinden langs de weg van onderhandeling.

25. Bij een meer pragmatische invalshoek hoort ook dat we nadenken over arrangementen die juist niet uitgaan van volledige participatie van alle landen. Het zou bijvoorbeeld ook erg effectief zijn indien slechts de tien grootste broeikasgasemitterende landen tot een afspraak zouden komen over een substantiële reductie, waarna het regime zich gradueel kan uitbreiden..$^{\circ}$ Voorts zal goed inzicht moeten bestaan in de verschillende belangen en belangengroepen die formeel en informeel in het besluitvormingsproces een rol spelen. Aan een klimaatconferentie wordt door tal van groepen deelgenomen, zoals TUNGO's, RINGO's, BINGO's en ENGO's.91 Voor de verdere bestudering van het internationale klimaatbeleid is juist een pragmatische invalshoek met oog voor de verschillende belangen en de mogelijkheden om tot effectieve afspraken te komen onmisbaar. Daarbij hoeft het niet zo te zijn dat er één

88 Zie de literatuur waaraan ik heb gerefereerd in Marjan Peeters (2008c).

89 Mathias Friman, Björn-Friman Linnér (2008), p. 343.

90 Jonathan B. Wiener (2007) stelt dat een internationaal verdrag tussen de tien grootste emitterende landen al zeer effectief is, p. 116.

91 Tungo's: trade union ngo's; Bingo's: business and industrial ngo's; Ringo's: research and independent ngo's, Engo's: environmental ngo's. Het onderzoeksinstituut Metro is in zijn hoedanigheid van RINGO als waarnemer toegelaten tot de internationale bijeenkomsten. 
uniforme afspraak is tussen ruim 190 landen, maar kan sprake zijn van diverse arrangementen en dus een meer divers pakket dat beter aansluit bij de wensen van de deelnemers en daarmee mogelijk zelfs effectiever kan zijn. $9^{2}$

26. Een van de belangrijke vragen op dit moment is in hoeverre het door het Kyoto Protocol geregelde kader nog levensvatbaar zal zijn. Het Protocol is een interessant internationaal experiment, met emissiereductieafspraken,emissiehandel, en een handhavingsregime. Er zijn besluitbevoegdheden in geregeld, en in feite zien we dat hiermee een internationaal bestuursrecht aan het ontstaan is. Bovendien heeft dat systeem al laten zien dat er veroordelingen tot stand komen: zo heeft de ingestelde handhavingscommissie in 2008 vastgesteld dat Griekenland bepaalde rapportageverplichtingen - uitermate belangrijk voor het vaststellen van de naleving van gestelde emissiereductieverplichtingen en voor een goed functioneren van het emissiehandelssysteem - niet is nagekomen. 93 Dit zijn belangrijke bouwstenen op weg naar een juridisch regime voor de aanpak van het klimaatprobleem, waarvan immers ook een handhavingsmechanisme onderdeel behoort te zijn. Het mooie is dat indien een land met emissiereductieverplichtingen niet voldoet aan de handhavingsverplichtingen, het geen gebruik kan maken van de flexibiliteit die de internationale emissiehandel biedt voor de naleving van de emissiereductieverplichtingen. Aldus is er een prikkel ingebouwd om de registratie en rapportageverplichtingen in orde te hebben.

27. Het in 1997 totstandgekomen en in 2008 van kracht geworden Kyoto Protocol faciliteert overigens reeds internationale emissiehandel teneinde op een flexibele en goedkopere manier nationale

92 Jospeh E. Aldy, Robert N. Stavins (ed.) (2007), met daarin onder meer David G. Victor (2007).

93 Enforcement branch of the Compliance Committee, CC-2007-1-8/Greece/EB, beslissing van 17 april 2008. Overigens is in casu geen sprake van een unanieme beslissing. Art. 18 Kyoto Protocol regelt voorts dat bindende gevolgen pas van toepassing kunnen zijn na wijziging van het Kyoto Protocol; niettemin wordt vastgesteld dat Griekenland niet zou kunnen deelnemen aan de emissiehandelsvoorzieningen (zie ondermeer art. 6(1)(c) Kyoto Protocol). Zie precies: Decision 27/CMP.1, Procedures and mechanisms relating to compliance under the Kyoto Protocol, Annex section XV, paragraph 4. Inmiddels is terzake Griekenland vastgesteld dat het nalevingstekort verdwenen is (CC-2007-1-13/Greece/EB, 13 november 2008). Ook inzake Canada is een vraag van niet-naleving behandeld, waarna later is geconstateerd dat Canada alsnog aan verplichtingen voldoet. 
emissiereductieverplichtingen na te leven. Het Kyoto Protocol regelt hiervoor drie systemen: in de eerste plaats is dat emissiehandel tussen de in economische zin ontwikkelde verdragstaten waarvoor een emissiereductieverplichting is vastgesteld. In de tweede plaats zijn dat twee sterk op elkaar lijkende en op projectbasis berustende emissiehandel vormen, bekend als Joint Implementation en het Clean Development Mechanism. In essentie houden deze vormen in dat voor een concreet project waarmee een broeikasgasreductie wordt gerealiseerd een verhandelbaar emissierecht in de vorm van een emissiekrediet ontstaat. Het Clean Development Mechanism ziet in het bijzonder op de mogelijkheid om emissiereducties te bewerkstelligen in ontwikkelingslanden: een dergelijke investering zou dan moeten leiden tot een broeikasgasemissiereductie die additioneel is, en dus zonder deze investering niet zou hebben plaatsgehad. Het ontwikkelingsland dient daarbij te verklaren dat het project bijdraagt aan 'duurzame ontwikkeling'.

Ik ben erg bezorgd over dit Clean Development Mechanism, en kijk uit naar verder wetenschappelijk onderzoek dat de integriteit en het mogelijke optreden van nadelige en mogelijk zelfs perverse effecten bekijkt. Algemeen bekend is reeds dat de minst ontwikkelde landen ook het minst profiteren van CDM-investeringen, aangezien deze landen minder aantrekkelijk zijn om in te investeren. Ook kan er een rem ontstaan op de ontwikkeling van de nationale milieuwetgeving in een ontwikkelingsland: zo heb ik in 2004 in Jakarta het idee vernomen om geen nieuwe nationale milieuwetgeving uit te vaardigen die het vereiste van additionaliteit in gevaar zou brengen. 94

Een grote moeilijkheid bij het CDM-systeem is de ongelijkheid in deskundigheid tussen enerzijds ontwikkelde landen, die graag willen kopen om zo in eigen land minder inspanningen te hoeven verrichten, en anderzijds de ontwikkelingslanden waar juristen minder talrijk en minder opgeleid zijn. 95 In de juridische literatuur wordt voorts aandacht gevraagd voor een betere vormgeving van het besluitvormingsproces, waarbij in feite gewerkt wordt aan het bouwen aan een internationaal bestuursrecht voor de beheersing

94 Workshop te Jakarta, augustus 2004.

95 Joyeeta Gupta wees reeds op onbalans inzake de internationale verdragsonderhandelingen in haar boek 'Our simmering planet': Gupta (2001). Zie voorts hoe ingewikkeld het is om de effecten van CDM te beoordelen: Steffen Kallbekken (2007). 
van het regime van internationale emissiehandel. Terzake het CDM worden reeds door een op grond van het Kyoto Protocol ingesteld comité (het CDM Executive Board) beslissingen genomen, en de vormgeving, uitvoering en de mogelijkheid van beroep inzake deze procedure zijn zaken die nog verder ontwikkeld moeten worden. ${ }^{96}$ Bovendien wordt betoogd dat het CDM mechanisme in essentie te bureaucratisch is, en dat er beter een eenvoudiger systeem van emissiehandel tussen landen kan worden vormgegeven, waarbij aan ontwikkelingslanden voldoende ruime rechten worden toegekend. 97 In dat laatste geval, echter, speelt het moeilijke punt hoe een voldoende effectief handhavingsregime kan worden gecreëerd. $9^{8}$

De internationale emissiehandelsregimes zouden alleen verder moeten worden ontwikkeld indien tegelijkertijd wordt voorzien in een sterk juridisch kader.99 We zien dat juist de toepassing van de internationale emissiehandel de totstandbrenging van een stukje internationaal bestuursrecht nodig maakt en dus de aanwezigheid van "the rule of law" in het internationale domein bevordert. In die zin is er sprake van een mooi ontwikkelingsproces, zowel in milieurechtelijke als in bestuursrechtelijke betekenis. De mogelijkheid om aan het systeem van emissiehandel mee te doen is in feite een impuls voor staten om zich aan te sluiten bij een internationaal regime voor controle en handhaving. We moeten echter voor ogen blijven houden dat zodra broeikasgasemissiehandel wordt toegepast in een situatie waar het recht nog onvoldoende ontwikkeld is er een risico wordt gelopen op fraude en corruptie.

28. Een dergelijk risico wordt ook gelopen in de inmiddels wereldwijde vrijwillige broeikasgasemissiemarkt, waarbij $u$ en ik, bedrijven en overheden hun broeikasgasemissies kunnen laten compenseren. Het is een instrument dat helpt om klimaatneutraal te zijn: als een bedrijf of een overheidsdienst zijn emissies heeft teruggedrongen, kan het de restemissies compenseren door te investeren in een

96 Charlotte Streck, Jolene Lin (2008).

97 Joseph E. Aldy en Robert N. Stavins (ed) (2007) p. 12 en later ook p. 358 in dat boek, zie eerder ook Richard B. Stewart en Jonathan B. Wiener (2003).

98 Thomas Schelling (2007) p. 344.

99 David G. Victor (2001). Jon Hovi, Bjart Holtsmark, Cap-and-trade or carbon taxes? The feasibility of enforcement and the effects of non-compliance, International Environmental Agreements (2006) 6:137-155. 
emissiereductie elders. $U$ kent misschien wel de advertenties waarin staat dat bedrijven of overheden klimaatvriendelijk dan wel klimaatneutraal zijn of zullen worden. Of $u$ kent misschien de advertenties waarbij $u$ wordt aangeboden uw klimaatuitstoot te compenseren. Op vliegvelden, zoals bijvoorbeeld op het vliegveld te Eindhoven, staat in de wachtruimte een pinapparaat gereed waarmee ter plekke de klimaatuitstoot van de vlucht kan worden gecompenseerd. Voor allerhande soorten activiteiten worden inmiddels compensaties aangeboden, zoals vliegreizen, uitgaven met een creditcard ${ }^{100}$, en theater- en concertbezoeken ${ }^{101}$. Het is zelfs mogelijk om een 'carbon credit' aan iemand cadeau te doen. ${ }^{102}$ In een recent onderzoek heb ik betoogd dat ook in deze markt de rol van de overheid onmisbaar is. $U$ als burger kunt als consument maar moeilijk controleren of de aangeboden compensatie betrouwbaar en integer is. Cruciaal bij deze systemen is dat de compensaties vaak in ontwikkelingslanden plaatsvinden, omdat de compensaties daar goedkoper zijn. Met name bosaanplant is een goedkope wijze van compensatie, alhoewel daaraan haken en ogen zitten, waaronder de vraag of met de belangen van de lokale bevolking en lokale omgeving correct wordt omgegaan. In het Verenigd Koninkrijk heeft de overheid zich het belang van een betrouwbare compensatiemarkt sterker aangetrokken dan in Nederland: onze minister van milieu stelde zich op het standpunt dat de integriteit en betrouwbaarheid door de markt zelf moet worden verzekerd..$^{103 \mathrm{lk}}$ ben echter tot de conclusie gekomen dat het Britse model, waar een certificatiesysteem wordt ontwikkeld door de overheid, en dat door marktpartijen verder ter hand kan worden genomen onder leiding van een accrediterend orgaan, de voorkeur verdient. ${ }^{104}$

100 Bijvoorbeeld in Nederland: https://www.visagreencard.nl, bezocht op 30 augustus 2008.

101 Bijvoorbeeld, het Montreal Internationaal Jazz Festival 2008 was klimaatneutraal (aangekondigd op website van planetair, http://planetair.ca).

102 www.carbonneutral.com, bezocht op 12 augustus 2008.

103 Kamerstukken II 2007/08, 31 209, nr. 12 en nr. 32.

104 Draft Code of Best Practice for Carbon Offset Providers, 19 februari 2008, http:// www.defra.gov.uk/environment/climatechange/uk/carbonoffset/pdf/carbon-offsetcodepractice.pdf, bezocht op 3 september 2008 (vanwege een nieuw klimaatministerie in het Verenigd Koninkrijk kan het zijn dat de website aangepast wordt). Zie ook: House of Commons, The Environmental Audit Committee (2007). 
29. In de milieucommissie van het Engelse Lagerhuis vindt voorts een interessant debat plaats over de verdere uitbouw van de verplichting voor burgers om hun broeikasgassen, die voornamelijk worden uitgestoten via de verwarming en koeling van huizen en via transport, maar ook via de aankoop van bepaalde producten, te compenseren. Er wordt zelfs gesproken over verplichte compensaties, maar een wettelijke regeling daarvoor is nog niet geïnitieerd. ${ }^{105}$ Daarnaast is in het Verenigd Koninkrijk gesproken over een systeem van persoonlijke broeikasgasemissierechten, hetgeen wederom op veel sympathie kon rekenen van de genoemde milieucommissie. ${ }^{106}$ Dit past bij het pleidooi in de literatuur dat er naast aandacht voor statelijke verplichtingen ook aandacht moet zijn voor individuele verplichtingen van burgers, zowel van welvarende burgers in welvarende landen als die in ontwikkelingslanden zoals China. ${ }^{107}$ Het nader ontwikkelen van passende instrumenten is hierbij een volgende uitdaging.

30. $U$ ziet, op nationaal niveau, en in het bijzonder in het Verenigd Koninkrijk worden interessante initiatieven ondernomen voor de regulering van broeikasgassen. Het systeem van internationaal afgesproken emissiereductieverplichtingen geeft in principe ook die ruimte voor specifiek nationaal beleid: staten zijn verplicht om in een periode een bepaalde emissiereductie te bereiken, maar de wijze waarop dat wordt gedaan kan op velerlei manier worden ingevuld. Deze differentiatie kan vele voordelen hebben, aangezien de oplossingen beter passen bij de nationale (rechts-) cultuur en bijvoorbeeld ook bij de nationale energiesituatie. Bovendien kan geleerd worden van verschillende benaderingen en verschillende wettelijke instrumenten ter invulling van de nationale emissiereductieverplichtingen.

31. Daarnaast zijn vernieuwingen denkbaar in de aanpak op internationaal niveau. Zo is het idee van internationale sectorale benaderingen in opkomst, waarbij één industrietak, zoals cement of staal, of een internationale dienstensector, zoals internationale luchtvaart of scheepvaart, geregeld zal worden. $U$ kunt zich

105 House of Commons, The Environmental Audit Committee (2007).

106 House of Commons, The Environmental Audit Committee (2007), p. 54.

107 Paul G. Harris (2008). 
voorstellen dat het geen zin heeft als een zuinige cement- of staaloven, die zo min mogelijk $\mathrm{CO}_{2}$ uitstoot, in Nederland gesloten wordt terwijl elders een oven wordt opgericht die gewoon op kolen gestookt gaat worden, en waarvan het product dan in Nederland geïmporteerd zal worden. Het Bali Actieplan vermeldt de mogelijkheid van sectorale benaderingen, waarbij we ons kunnen voorstellen dat landen in een apart akkoord een afspraak maken over de regulering richting de geselecteerde industrie.108 Ook is interessant de mogelijkheid van afspraken tussen wereldwijd met elkaar concurrerende bedrijven zelf. Het vinden van een model voor bindende emissiereductiedoelstellingen voor verdragspartijen én het creëren van mogelijkheden om een wereldwijd gevestigde industriesector te reguleren is een belangrijk onderwerp voor de nabije toekomst.

32. Ondertussen buitelen nieuwe plannen voor het verder vormgeven van de internationale markt over elkaar heen: met name is een nieuwe benadering in discussie die REDD is geheten: 'Reducing Emissions from Deforestation and Forest Degradation in Developing Countries'. Dit mechanisme beoogt de bescherming van bossen in ontwikkelingslanden onder de wereldwijde koolstofmarkt te brengen. ${ }^{109}$ De bescherming van bijzondere bossen en daarbij behorende biodiversiteit is een nobel streven; tegelijkertijd is het belang van de rijke landen duidelijk. Het gebruikmaken van deze REDD kredieten zou een goedkope manier zijn om koolstofemissies te compenseren." ${ }^{10} \mathrm{k}$ kan als jurist niet beoordelen of in natuurwetenschappelijk opzicht hier een effectief en betrouwbaar regime wordt opgetuigd."'Ook hier is het van cruciaal belang dat de emissiekredieten betrouwbaar en meetbaar zijn, dat er geen lekken

108 Bali Action Plan. Decision 1/CP. Report of the Conference of the Parties, on its thirteenth session, held in Bali from 3 to 15 December 2007; zie verder ook working paper Elisa Malathouni, Denise Prevost, Marjan Peeters (2009). In de door het Europese Parlement in eerste lezing aangenomen tekst tot herziening van de broeikasgasemissiehandelsrichtlijn wordt eveneens verwezen naar de mogelijkheid van een internationale sectorale overeenkomst, zie het voorgestelde artikel 10b.

109 Environmental Defense Fund (2008), Ian Fry (2008).

110 Zie ook N. Stern (2007), executive summary, p. xiii.

111 Stern wijst er op dat ook het verlies aan opbrengsten door het land niet op alternatieve en mogelijk meer lucratieve wijze te gebruiken (zoals landbouw), verdisconteerd moeten worden. Stern (2007) p. xxvi. 
zijn, en dat de marktconforme benadering niet ten koste gaat van het welzijn van de lokale bevolking. Vanuit de economische literatuur leer ik dat de goedkope emissierechten die bereikt kunnen worden via bosbehoud en aanplant van bos averechts kunnen werken, omdat de prijs voor koolstof lager zal zijn waardoor er een minder sterke prikkel is voor transities naar nieuwe energie. ${ }^{12}$ Dit is dan ook een van de redenen waarom de Britse overheid voor de vrijwillige broeikasgasmarkt geen emissierechten voor bos wil accepteren.

112 N. Stern (2007), p. xxvi. 


\section{Europees en nationaal klimaatbeleid}

33. Gelet op de moeilijkheden die de totstandbrenging van een effectief internationaal klimaatbeleid belemmeren, is het juist van belang dat er op regionaal, nationaal en lokaal niveau initiatieven worden genomen. Er bloeien vele bloemen, zowel binnen bestaande kaders als ook nieuwe. Ook kan moedig bestuur worden ontwaard: ik duid hiermee op de beslissing van GS Drenthe tot weigering van een vergunning ingevolge de Wet milieubeheer voor een afvalverbrandingsinstallatie vanwege het feit dat de vrijkomende restwarmte niet zou kunnen worden gebruikt op de gekozen locatie. De restwarmte, die anders verloren zou gaan, zou het jaarlijks gasverbruik van ca. 53.000 huishoudens betreffen. ${ }^{1{ }^{3}}$ Vanuit een optiek van een doelmatig gebruik van energie zou een dergelijke afvalverbrandingsinstallatie in beginsel gelegen moeten zijn in de nabijheid van bedrijven en gebouwen waar de restwarmte toegepast kan worden. Uiteraard moet dit belang worden afgewogen tegen andere milieubelangen, zoals de vraag of afvalverbrandingsinstallaties in de buurt van woonwijken of "werkwijken" gevestigd zouden moeten worden, en de afstand van afvaltransporten. Vanwege het karakter van de integrale vergunningverlening moet immers een afweging van de verschillende relevante milieuaspecten plaatsvinden."14 Momenteel ligt de zaak voor bij de Afdeling bestuursrechtspraak van de Raad van State, waar hopelijk een voldoende heldere uitspraak wordt gedaan omtrent de vraag of een aanvraag om een milieuvergunning voor een installatie mag worden geweigerd omdat op de aangevraagde locatie de restwarmte onvoldoende kan worden benut. Hier speelt de vraag of dit kan binnen het kader van de Wm, dan wel of dit via het planologische spoor geregeld zou moeten worden. Voor de nabije toekomst zullen de Ministers van EZ en VROM overigens de bevoegdheid krijgen om in aanvulling op de Wet milieubeheer regels te stellen aan het nuttige hergebruik van restwarmte door producenten, waaronder een verbod dan wel een heffing op onbenutte restwarmte. ${ }^{15}$

113 Aldus het verweerschrift in deze zaak.

114 Aldus kan worden afgeleid uit ABRvS 28 oktober 2008, 200707551/1, LJN: BG3360 (SITA Roosendaal), in het bijzonder overweging 2.8 .

115 EK 2007-2008, 29 048, A, Gewijzigd voorstel van wet 3 juli 2008, artikel 32. 
34. Het idee van Wiener om het klimaatbeleid te gieten in een wettelijk kader waarin alle bronnen en gassen geregeld worden, met een centrale rol voor emissiehandel, is vooralsnog niet het model dat in de EU wordt gevolgd. Op Europees niveau is een groot aantal besluiten, richtlijnen en verordeningen tot stand gebracht, hetgeen ertoe leidt dat het niet eenvoudig is om het Europese klimaatbeleid te begrijpen." ${ }^{16}$ Daarnaast moet voor een goed begrip van de effectiviteit van het Europese optreden ook het nationale klimaatbeleid bezien worden: het milieubeleidsterrein is immers een gedeelde bevoegdheid tussen lidstaten en EU, en daarbij zal de EU ingevolge het subsidiariteitsbeginsel slechts moeten optreden indien lidstaten dat niet in voldoende mate kunnen doen. Het klimaatbeleid in de EU komt dus gedeeld tot stand, met zowel Europese wetten als nationale wetten. De nationale wetten zijn vaak nodig ter uitvoering van de Europese wetten; bovendien zijn nationale wetten nodig voor terreinen die niet door de EU-wetgeving bestreken worden, en voor onderwerpen waar de nationale overheden een verdergaand beleid willen en mogen voeren dan waarin de Europese wetgeving voorziet.

Voorlopig is het dus nog een vraag of we in de EU zullen toegroeien naar het interessante idee van een volledige koolstofmarkt, waarin alle sectoren en gassen besloten liggen. Er worden wel enkele stappen gezet op weg daarnaar toe, zoals de uitbreiding van de koolstofmarkt naar de luchtvaart."17 De herziene richtlijn broeikasgasemissiehandel biedt voorts aan lidstaten de mogelijkheid tot graduele uitbreiding van het systeem naar andere bronnen en broeikasgassen. ${ }^{118}$ De gedeelde bevoegdheid op het terrein van het milieu in combinatie met het subsidiariteitsbeginsel maakt dat genuanceerd bezien moet worden wat op nationaal niveau en wat op Europees niveau geregeld moet worden. De realiteit is dat voorlopig met een pakket van verschillende Europese en nationale wetgevingsmaatregelen moet worden gewerkt, om zodoende alle sectoren en broeikasgassen te bereiken.

116 Zie hierover Marjan Peeters en Kurt Deketelaere (2006) en Marjan Peeters (2007a).

117 Dit betreft de nieuwe richtlijn 2008/101/EG van het Europees Parlement en de Raad van 19 november 2008 tot wijziging van richtlijn 2003/87/EG om luchtvaartactiviteiten op te nemen in de regeling voor de handel in broeikasgasemissierechten binnen de Gemeenschap, PB EU 13.01.2009, L8/3.

118 Art. 24 van de op 17 december door het Europees Parlement aangenomen tekst, en voorts ook art. 24a specifiek voor projecten; zie Europees Parlement (2008b). 
In het kader van het Europese klimaatbeleid zijn reeds vele soorten wetten tot stand gekomen, met verschillende reguleringsstijlen en verschillende onderwerpen, waaronder regels voor producten zoals gloeilampen, auto's en brandstoffen. ${ }^{119}$ Zo is gekozen voor een apart juridisch kader voor duurzame energie, dat behalve klimaatbescherming ook andere doelen dient, zoals energiezekerheid en verkleining van de afhankelijkheid van buiten de EU gelegen energieleveranciers. ${ }^{120} \cup$ zult zich misschien afvragen waarom voor het klimaatdeel niet eenvoudig kan worden volstaan met emissiehandel. Dat zou ook zeker kunnen, mits er scherpere emissiereducties zouden worden vastgesteld. In de literatu ur is dan ook al wel gesteld dat alleen regelgeving gericht op reductie van broeikasgassen voldoende zou zijn, hetgeen in ultimo zou impliceren dat de Europese maatregelen om lidstaten aan hernieuwbare energiedoelstellingen te houden overbodig zouden zijn. ${ }^{21}$ Echter, de broeikasgasreductiedoelstellingen zoals nu zijn vastgesteld voor 2020 zijn te laag om op indirecte wijze hernieuwbare energie in belangrijke mate te stimuleren, zodanig dat er sprake zou zijn van $20 \%$ hernieuwbare energie in 2020 . Daarom is behoefte aan een extra pakket aan regels ter stimulering van duurzame energie, met ingewikkelde voorzieningen zoals de handel in bewijzen voor duurzame energie, 'garanties van oorsprong geheten'.

De in december 2008 uitonderhandelde richtlijn voor duurzame energie beoogt een kader te geven voor een transitie naar hernieuwbare energie. ${ }^{122}$ Als echter via regelgeving de werkelijke kosten van fossiele energie zou den worden doorberekend, dan zouden vormen van hernieuwbare energie nu reeds (windenergie op land) dan wel op korte termijn (windenergie op zee en bio-elektriciteit)

11 Zie Europees Parlement 2008(d) en (e), met emissie-(rapportage)eisen voor brandstof en auto's; terzake gloeilampen wordt in maart 2009 een eerste besluit tot uitfasering verwacht: Europese Commissie (2008).

120 Pedro Linares', Francisco Javier Santos, Mariano Ventosa. Pedro Linares e.a. (2008), p. 391.

121 Pedro Linares', Francisco Javier Santos, Mariano Ventosa (2008).

122 Regieorgaan energietransitie, 2008, p. 25 geeft hieromtrent een interessante gedachte, met een onderscheid tussen een economische zienswijze en een innovatieve zienswijze. Echter, de mogelijkheid van een streng broeikasgasemissiehandelssysteem met een laag plafond zou in de overwegingen meegenomen moeten worden. 
concurrerend kunnen zijn met energie uit fossiele brandstoffen. ${ }^{23}$ In die zin zou de regelgeving gericht op duurzame energie niet in een apart pakket moeten zitten, maar in een integraal pakket waarin zowel fossiele energie als duurzame energie gereguleerd worden.

35. In de Europese benadering neemt het vaststellen van lidstatelijke emissiereductieverplichtingen - waarin ook een mogelijkheid tot handel van rechten tussen lidstaten is begrepen - en het Europese broeikasgasemissiehandelssysteem voor bedrijven niettemin een centrale rol in. ${ }^{22}$ Het is bijzonder mooi dat ondanks de financiële crisis er in december 2008 een akkoord tot stand is gebracht waarbij de milieudoelstelling om in 202020 procent van de broeikasgasemissies in de EU te reduceren in stand is gebleven, zij het dat een zeer aanzienlijk deel van deze reducties verkregen mag worden via de internationale emissiehandel en dat is een punt waarover ik me eerder kritisch uitliet. Het komt er op neer dat bedrijven $50 \%$ van hun verplichting kunnen compenseren met kredieten via buiten de EU verkregen emissiekredieten; daarnaast mogen ook lidstaten tot een vastgesteld plafond van dergelijke kredieten gebruik maken, waarbij de mogelijkheid wordt gegeven om het quotum aan te gebruiken buitenlandse kredieten over te dragen aan een andere lidstaat. ${ }^{25} \mathrm{Ik}$ vertel $\mathrm{u}$ dit nu, het gebruikmaken van buiten de EU gecreëerde kredieten is een wezenlijk onderdeel van het aangenomen klimaatpakket, maar de Europese Commissie verzuimt vreemd genoeg in haar samenvatting voor de Europese burgers te vermelden dat de doelstelling van min $20 \%$ in 2020 voor een groot deel via deze buitenlandse investeringen bereikt zal worden. ${ }^{26}$ Een belangrijk onderzoekspunt voor de komende jaren blijft hoe via juridische maatregelen de integriteit van de handel in deze buitenlandse kredieten kan worden gewaarborgd.

123 Zoals gesteld door het Regieorgaan energietransitie, 2008, p. 27.

124 Zie de op 17 december aanvaarde teksten door het Europees Parlement (2008a en 2008b).

125 Zie respectievelijk Europees Parlement (2008b) art. 11a en Europees parlement (2008a) art. 5 . In het laatste artikel staat onder meer dat jaarlijks maximaal voor $3 \%$ van de in 2005 in totaal geverifieerde emissies via dergelijke offsets mag worden gebruikt, en dat dit quotum mag worden overgedragen aan een andere lidstaat, of naar een ander kalenderjaar. 
Bovendien is er veel kritiek gekomen op het akkoord omdat veel van de broeikasgasrechten gratis verstrekt zullen worden aan de bedrijven. Deze aanpassing ten opzichte van het voorstel van de Commissie heeft echter de milieudoelstelling voor 2020 niet bedreigd. Als we de Europese prestatie zetten naast andere belangrijke spelers op het wereldtoneel, dan kunnen we echter vaststellen dat de EU qua bindende emissiereductieverplichtingen momenteel voorop loopt. Bovendien zitten er enkele interessante nieuwe elementen in het klimaatpakket, waaronder de al genoemde regeling van handel tussen lidstaten, een nadere regeling voor de wijze waarop een tekortschietend nationaal klimaatbeleid moet worden hersteld, de veiling van de broeikasgasrechten en ook een voorziening om in te grijpen bij een ongewenste prijsontwikkeling van de emissierechten.

36 In het onderhandelde en aanvaarde Europese klimaatpakket zijn emissiereductieverplichtingen afgesproken die door de lidstaten in 2020 moeten zijn bereikt. Onze promovendus Javier de Cendra de Larragàn zal aan de hand van rechtsbeginselen analyseren hoe de verdeling van emissiereductieverplichtingen over lid-staten (en voorts ook de vrijstelling van veilen voor bronnen in Oost-Europese lidstaten) nader verklaard kan worden. De statelijke emissiereductieverplichtingen hebben overigens géén betrekkingopde industrie die onder hetEuropese broeikas-gasemissiehandelssysteem valt. Dit betekent dat de lidstaten ervoor moeten zorgen een nationaal klimaatbeleid te voeren (daarbij vele Europese regels in achtnemend) dat zal leiden tot de afgesproken emissiereductieverplichting. Een bijzonder punt van aandacht is de vraag hoe nu kan worden vastgesteld dat de lidstaten inderdaad de gestelde emissiereductieverplichting hebben gehaald; in feite is dit dezelfde vraag als hoe kan worden vastgesteld dat de ontwikkelde landen de Kyoto emissiereductieverplichting in het jaar 2008-2012 zullen hebben gehaald. Interessant is dat de nieuwe regeling enerzijds jaarlijkse bindende emissiereductiedoelstellingen kent en anderzijds flexibiliteit voor de lidstaten om deze emissiereductiedoelstellingen te bereiken, waaronder ook interstatelijke handel. ${ }^{17}$ Bovendien wordt voorzien in een verplichting om een te hoge uitstoot te compenseren met een extra reductie in het volgende jaar, en om een herstelplan op

127 Europees Parlement (2008a) art. 3; zie ook de in dat artikel opgenomen mogelijkheid om een deel van de emissieruimte van een volgend jaar te 'lenen' en niet benodigde emissieruimte te 'sparen', art. 3(3). 
te stellen en in te dienen bij de Europese Commissie teneinde weer in lijn te komen met de verplichtingen. ${ }^{28}$ Ondanks deze verbeteringen blijt in essentie relevant de vraag of de Europese juridische structuren sterk genoeg zijn voor dit marktconforme instrument, met name waar het gaat om de correcte vaststelling van de broeikasgasemissies in een lidstaat en de eventueel benodigde handhaving richting lidstaten. Dit onderwerp zal deel uit blijven maken van mijn onderzoeksagenda.

37. Inmiddels heeft het Europese broeikasgasemissiehandelssysteem, dat op een groot deel van de industrie van toepassing is, betrekking op ongeveer 10.000 installaties, op $40 \%$ van de broeikasgassen en op $50 \%$ van de $\mathrm{CO}_{2}$-emissies. Samen met Michael Faure heb ik onlangs een congres gehouden en een boek gepubliceerd over dit systeem, waarbij we met een groep van auteurs een aantal kritische noten hebben gekraakt over de nu voorgestelde herziening van het in 2003 van kracht geworden systeem. ${ }^{22}$ Het lijkt wel alsof de beleidsmakers bij de Europese Unie al veel beter snappen dan de wetenschappers hoe het instrument werkt. Waar wij nog vragen stellen en verder willen nadenken over de vormgeving van het instrument, specifiek voor het klimaatprobleem, werd in de EU het instrument in 2003 in sneltreinvaart geïntroduceerd en na enkele jaren alweer fundamenteel aangepast. Tijdens het onderhandelingsproces dat het Europese wetgevingsproces zo kenmerkt, zijn bovendien in korte tijd en in feite onder hoge politieke druk belangrijke wijzigingen aangebracht. Het uiteindelijke resultaat is een drastisch vernieuwde en tamelijk complexe regeling voor broeikasgasemissiehandel.

De nu aangenomen aanpassing van de Europese broeikasgashandel betekent voorts een verregaande centralisering van het instrument, waarbijvoordeindustrieeen indeEUvastgesteldemissiereductieplafond zal gaan gelden. Tot op heden zijn het de lidstaten die dat mogen bepalen. Het lijkt me echter een illusie dat het nieuwe voorstel een optimale vormgeving van het instrument zou betekenen, en in die zin is het jammer dat de oorspronkelijke, op zich ook niet perfecte methode niet tot verdere wasdom is kunnen komen.130 Het nieuwe systeem roept weer nieuwe lastige vragen op. Zo is al gewezen op het

128 Europees Parlement (2008a) art.7.

129 Michael Faure, Marjan Peeters (2008).

130 Marjan Peeters (2008d). 
mogelijk optreden van een waterbedeffect, waarmee wordt bedoeld dat het niet meer zinvol is voor een lidstaat om verdergaande eisen aan de industrie te stellen omdat de emissieruimte in een ander land wordt opgevuld. ${ }^{31}$ Voorts vormt het omgaan met het koolstoflek-de mogelijke verplaatsing van industrie naar landen waar minder vergaande klimaatmaatregelen worden getroffen, in Engelse terminologie 'carbon leakage' genoemd - een heet hangijzer. $U$ merkt al misschien hoe technisch de bespreking wordt van de vormgeving van een maatregel als broeikasgasemissiehandel, waar we moeten nadenken over waterbedeffecten en koolstoflekken. Daarbij moeten we ons realiseren dat achter deze vormgevingsdiscussie grote belangen schuilen: juist doordat de emissie van broeikasgassen schaarser wordt en aan een prijs wordt verbonden, betreft het broeikasgasemissiehandelssysteem een ingrijpende overheidsinterventie aangaande belangrijke economische activiteiten.

38. Het instrument van de Europese broeikasgasmarkt vormt een van mijn centrale onderzoeksonderwerpen, waarover ik al veel heb gepubliceerd. Ik wil vandaag slechts enkele onderwerpen aanstippen van het nieuwe systeem die naar mijn mening aandacht behoeven in nader onderzoek. ${ }^{132}$

- In de eerste plaats wil ik er op wijzen dat het nog in verregaande mate onduidelijk is hoe het nieuwe systeem precies zal luiden en welke effecten zullen optreden. Dit heeft enerzijds te maken met het feit dat er nog belangrijke uitvoeringsbesluiten genomen zullen moeten worden, met name op Europees niveau. Het heeft ook te maken met het feit dat er nieuwe en daarmee onbekende methodes worden gehanteerd, waaronder het veilen van de broeikasgasemissierechten. Daarbij komt dat de besluitvorming over het voorstel van de Commissie in zeer hoog tempo heeft plaatsgevonden, met op het laatste moment enkele politieke compromissen, waardoor de kwaliteit van de besluitvorming en waarschijnlijk ook de duidelijkheid van de teksten onder druk hebben gestaan.

- De Europese Commissie legt veel nadruk op de milieueffectiviteit doordat er een pad wordt uitgestippeld met emissiereducties tot

131 Netherlands Environmental Assessment Agency (2008).

132 De tekst van deze rede is afgesloten vlak na de stemming van het Europees Parlement op 17 december 2008 de definitieve teksten moeten nog worden gepubliceerd. 
2020. Zij besteedde echter in haar voorstel tot herziening van de richtlijn maar beperkt aandacht aan de vraag welke uitwerking de marktwerking zal hebben, en of er een noodzaak tot bijsturen is gedurende de handelsperiode die loopt van 2013 tot en met $2020 .{ }^{33} \mathrm{Het}$ is immers niet uitgesloten dat er externe factoren zijn die tot ongewenste effecten leiden, zoals een om economische redenen onaanvaardbaar geachte stijging van de prijs van de emissierechten; zo is onzeker wat bijvoorbeeld een oliecrisis kan betekenen voor de handel in koolstofemissies. ${ }^{34}$ Daarnaast zouden er nieuwe natuurwetenschappelijke inzichten kunnen ontstaan die noodzaken tot een vermindering van de hoeveelheid uitgegeven rechten. De Commissie besteedde in het voorstel tot aanpassing van het broeikasgasemissiehandelssysteem geen serieuze aandacht aan de vraag of ingrijpen in de broeikasgasmarkt nodig zou zijn. Vanuit een juridisch maar ook economisch oogpunt is het ingrijpen in een systeem van uitgegeven verhandelbare rechten als zodanig een delicaat punt, en het is dus van belang om grondig aandacht te besteden aan een goede vormgeving van bevoegdheden daartoe en de uitvoering daarvan. ${ }^{35}$ Er zijn overigens verschillende mogelijkheden om in te grijpen in een emissierechtenmarkt: gedacht kan worden aan een vooraf aangekondigde dan wel later vast te stellen maximumprijs van de broeikasgasemissierechten (in engelse terminologie een "price cap"). ${ }^{136}$ Een andere mogelijkheid is dat door de overheid actief wordt bijgestuurd door rechten te kopen of extra rechten uit te geven. Een prijsplafond kan politiek gewenst zijn ter bescherming van die bedrijven die onder emissiehandel vallen terwijl hun internationale concurrenten elders in mindere mate of niet onderhevig zijn aan klimaatverplichtingen. ${ }^{37}$ De

133 Commissie van de Europese Gemeenschappen (2008c).

134 IPCC (2007) wijst op p. 61 op de onzekerheid van de prijsontwikkeling van de emissierechten; zie ook het Stern rapport dat aangeeft dat de prijs van fossiele brandstof en de wijze hoe daarop gereageerd wordt moeilijk te voorspellen is. Overigens veronderstelt Stern dat er een overvloedig aanbod fossiele energie zal zijn (p. xiv).

135 Overigens kan het systeem ook zelf voorzieningen bevatten om prijsfluctuaties op te vangen, te weten door 'banking and borrowing'. Zie ook N. Stern (2007), p. xxiii.

136 Zie over een analyse inzake een prijsplafond voor de emissierechten J. Szolgayova, S. Fuss, M. Obersteiner (2008).

137 Zie in deze zin over de regionale broeikasgasemissierechtsystemen in de VS Erik B. Bluemel (2008). 
vraag of de overheid bevoegdheden zou moeten hebben om in te grijpen in een koolstofmarkt is in de (Europese juridische) literatuur vooralsnog onderbelicht gebleven. ${ }^{138} \mathrm{Het}$ lijkt echter van belang dat overwogen wordt of het nodig is een bevoegdheid te creëren tot ingrijpen in een emissierechtensysteem: juist omdat een marktconform instrument wordt geïntroduceerd, met bijbehorende onvoorspelbare werking van de markt, lijkt het aangewezen om te bezien of de resultaten van dat instrument, en ook de prijsontwikkeling, wel acceptabel zijn. Een van de grondleggers van het systeem van emissiehandel, de Canadese econoom J.H. Dales, voorzag reeds dat de overheid actief zou kopen en verkopen in een emissierechten markt. ${ }^{39}$ Dit is een dimensie die tot op heden nog maar weinig besproken wordt zowel in beleid als in de literatuur. In het voorstel van de Commissie werd ook niet ingegaan op eventuele bijsturingsmogelijkheden, terwijl de Europese Commissie bij de verdediging van de beslissing dat het Nederlandse NOx-emissiehandelssysteem staatssteun is in de zin van art. 87 lid 1 EG-verdrag opvallend genoeg heeft betoogd dat de Nederlandse overheid actief zou kunnen kopen en verkopen.140 Een opvallende wijziging is dan ook dat er in de uitonderhandelde tekst wél een mogelijkheid tot bijsturing van de prijsontwikkeling van de rechten is opgenomen, te weten een mogelijkheid om bij een excessieve prijsontwikkeling via het veilingsinstrument bij te sturen, door (vervroegd) meer rechten te veilen dan aanvankelijk gepland. ${ }^{44}$ In een veel ruimer perspectief wordt overigens reeds geopperd dat er een aparte overheidsorganisatie zou moeten komen die toeziet op de ontwikkeling van de koolstofmarkt, en die actief de prijs van de broeikasgasrechten beïnvloedt, net zoals we een Europese Centrale Bank kennen die de waarde van de

138 In de Nederlandse literatuur is wel aandacht besteed aan het ingrijpen in een vergunningenmarkt, meer specifiek in de context van schadevergoeding, zie Teuben (2005) en eerder ook de MDW werkgroep (2000).

139 J.H Dales (1968), m.n. p. 95.

140 Gerecht van Eerste Aanleg, T-233/04, Koninkrijk der Nederlanden versus Europese Commissie, 10 april 2008, par. 6o. Dergelijke overwegingen over een actieve(re) rol als overheid komen niet voor in het voorstel van de Commissie tot aanpassing van het broeikasgasemissierechtensysteem.

141 Europees Parlement (2008b): art. 29a; zie ook de rapportageplicht in art. 28. 
euro bewaakt. ${ }^{142}$ Met deze benadering zouden sterk wisselende prijzen in zekere mate ondervangen kunnen worden. Dergelijke prijsfluctuaties zijn overigens een reden waarom sommigen een voorkeur hebben voor de heffing, waarbij immers de overheid de prijs vaststelt. Dit soort discussies over de vraag of de prijs van de broeikasgasrechten door de overheid beheerst moet worden duiken nu langzamerhand op, en indien we echt willen toegroeien naar een koolstofmarkt dan is het nodig dat de discussie over de taak van de overheid inzake het bijsturen van de emissierechtenmarkt ten volle gevoerd gaat worden.

- Voorts weten we nog steeds niet welke allocatiemethode de voorkeur verdient in het geval van broeikasgasemissiehandel in een context waarbij er nog geen wereldwijd regime is. Ik wijs in dit verband op het feit dat een van de allocatiemethodes systematisch door de Commissie wordt afgewezen, zonder kracht van argumenten. Dit betreft het PSR-systeem, een systeem dat door een adviescommissie in 2001 is aanbevolen aan de Nederlandse regering maar overruled is door de broeikasgasemissiehandelrichtlijn. ${ }^{143}$ Het systeem wordt door een groep van Nederlandse bedrijven ondersteund, en samen met enkele collegae doen wij hier al enkele jaren onderzoek naar. Afgezien van de vraag of dit systeem überhaupt het beste, is het van belang dat er een afweging plaatsvindt waarbij reële opties tegen elkaar worden afgewogen. Opvallend is echter dat de Commissie het systeem radicaal blijft afwijzen. Bijzonder was dan ook de uitspraak van het Gerecht van Eerste Aanleg van 7 november 2007 waarbij een beslissing van de Commissie tot afwijzing van een specifieke toepassing van dit systeem door Duitsland werd vernietigd. ${ }^{144}$ Het PSR-systeem zou een mogelijke benadering kunnen zijn specifiek voor de internationaal concurrerende industrie, zo lang er geen effectief internationaal klimaatakkoord is. De uitonderhandelde herziening van de broeikasgasemissiehandelsrichtlijn legt nu de nadruk op ex ante benchmarks, en het is te bezien hoe in de nog op te stellen uitvoeringsregeling hier nader vorm aan wordt gegeven, daarbij

142 William Whitesell (2007) stelt een Greenhouse Gas Board voor, die via veilen van rechten invloed op de prijs uitoefent.

143 Zie hierover Marjan Peeters (2007b).

144 Gerecht van Eerste Aanleg zaak T-374/04, zie mijn annotatie in M en R 2008 jur. nr. 12. 
de in de richtlijn gestelde materiële criteria in acht nemend, waaronder het feit dat de benchmarks prikkels dienen te geven aan emissiereducties en energie-efficiënte technieken. ${ }^{145}$

- Interessant is voorts dat de in de literatuur al ruim aanbevolen optie van de veiling een plaats heeft gekregen in het nieuwe systeem. De industrie waarvan niet wordt vastgesteld dat die blootstaat aan een aanzienlijke dreiging van 'carbon leakage' zal via de veiling rechten moeten kopen, in die zin dat in $201320 \%$ van alle rechten op de veiling zal moeten worden gekocht, oplopend naar $70 \%$ in 2020. ${ }^{146}$ Er wordt wel gesteld dat vanwege de ruime definitie van 'carbon leakage' vermoedelijk maar een beperkt deel van de bedrijven de rechten via de veiling zal moeten kopen. ${ }^{147}$ Voorts wordt veilen verplicht voor de gehele energiesector, met een uitzonderingsmogelijkheid voor de energiesector met name in die landen die overwegend op kolen leunen (in Oost-Europa). Om van deze uitzondering, die als een overgangssituatie wordt gekenschetst, gebruik te kunnen maken zal aan een aantal voorwaarden moeten worden voldaan, zoals het opstellen van een nationaal plan voor onder meer de verbetering van de energieinfrastructuur. ${ }^{48}$ Dergelijke gehele of gedeeltelijke vrijstellingen van veilen kunnen niet los worden gezien van de vraag of er zogenaamde 'windfall profits' zullen ontstaan, doordat de marktprijs van de gratis verkregen rechten wordt doorberekend aan de consument. Het kan dus gebeuren, en het is al gebeurd in de eerste en tweede fase, dat bedrijven de rechten gratis krijgen maar uiteindelijk de kosten wel doorberekenen. In essentie blijft dit in perspectief van het beginsel 'de vervuiler betaalt' een onbevredigend effect, en is dit een belangrijk argument voor het toepassen van veilen. ${ }^{49}$

- De veiling van verhandelbare emissierechten wordt sterk gepromoot door de economische theorie, maar in de praktijk is er nog maar nauwelijks ervaring mee opgedaan. In de politieke onderhandelingen is de betekenis van veilen afgenomen, maar

145 Europees Parlement (2008b) art. 10a(1).

146 De gratis toedeling van rechten aan de "carbon leakage" sectoren staat in art. 10(12).

147 Nieuwsbrief Emissiehandel nr. 63, 23 december 2008.

148 Europees Parlement (2008b) art. 10c.

149 Zie uitgebreid over veilen en het beginsel de vervuiler betaalt: Jonathan Remy Nash (2000). 
het interessante is niettemin dat het nu een rol heeft gekregen en verder uitgevoerd moet worden. Mijn collega Stefan Weishaar, van huis uit econoom, heeft laten zien welke factoren onder meer relevant zijn voor de precieze vormgeving van de veiling, en mij is daarmee wel duidelijk geworden hoe complex dit instrument is. 150 Het vormgeven van veilen is dus waarlijk een nieuwe uitdaging voor de wetgevingsjurist. Een van de belangrijke vragen is of de overheid er op uit is om maximaal financieel voordeel te halen uit de veiling, dan wel de veiling zo zal vormgeven dat de overheidsinkomsten minder zullen zijn en de kosten voor de Europese bedrijven die meedoen aan de veiling dus lager. Inmiddels heeft de Nederlandse overheid in een akkoord met de energiesector aangegeven dat de veiling niet wordt gezien als een additionele inkomstenbron, maar als een allocatiemechanisme..$^{151}$ Hier ontstaat de vraag of de regels voor de veiling zoals die via de comitologieprocedure door de Commissie zullen worden vastgesteld deze ruimte zullen bieden aan de lidstaat Nederland. Voorts is de uitspraak van de Nederlandse overheid richting Nederlandse bedrijven in potentie gunstig voor alle Europese bedrijven die aan de Nederlandse veiling kunnen en willen meedoen. Het genoemde akkoord is overigens, anders dan een wetsvoorstel, niet behandeld door onze Tweede en Eerste Kamer, terwijl het een wezenlijke uitspraak bevat met betrekking tot de vormgeving van de veiling. Bovendien gaat het ook om de vraag hoe rijksfinanciën kunnen worden geworven. Uit de kamerstukken leid ik af dat het akkoord echter pas naar de Tweede Kamer is gezonden nadat daarom door een lid van de oppositiepartij is gevraagd. ${ }^{152}$

- Eerder vandaag heb ik al aangegeven hoe belangrijk het is dat het marktconforme instrument van emissiehandel vergezeld wordt van een sterke handhavingscomponent. Vaak wordt bij emissiehandel verwezen naar het succes van het in Amerika toegepaste systeem van emissiehandel voor zure regen, maar cruciaal is dat daar een sterk handhavingsbeleid is opgezet

150 Stefan Weishaar (2008).

151 Sectorakkoord Energie 2008-2020: Convenant tussen Rijksoverheid en energiebranches in het kader van het werkprogramma Schoon en Zuinig, 28 oktober 2008, overwegingen. Bijlage bij kamerstukken II 2007/2008, 31209, nr. 43.

152 Brief van de Minister van Economische Zaken aan de Tweede Kamer, 29 oktober 2008, Kamerstukken II 2007/2008, 31209, nr. 43. 
en bovendien een scherpe handhavingscultuur heerst. ${ }^{153}$ In een in 2006 gepubliceerd artikel heb ik uiteengezet dat bij broeikasgasemissiehandel in de EU opvallend veel vertround wordt op zelfcontrole door de bedrijven, gepaard gaande met de figuur van verificatie. De uitstoot van de broeikasgassen is echter onzichtbaar, en de rol van derden bij het nagaan of geen inbreuk wordt gemaakt op gestelde regels lijkt daarom uiterst gering. Anders dan een illegale afvalstort of een aantasting van een natuurgebied, zullen burgers of collega-bedrijven een illegale broeikasgasuitstoot niet met het blote oog kunnen constateren. De handhaving komt dus neer op de overheid, die daarbij voor de vraag of de emissiejaarverslagen accuraat zijn bijgestaan wordt door private instanties, verificateurs geheten. In Nederland is er voorts voor gekozen om de handhavingstaken bij emissiehandel te concentreren bij een centrale instantie, hetgeen in mijn opvatting geen overtuigende keuze is en bovendien haaks staat op de in Nederland overheersende integratiegedachte in de vorm van een 'one stop shop'. Er zou ook iets voor te zeggen zijn om toezicht en handhaving van broeikasgasemissiehandel te laten aansluiten bij reeds bestaande handhavingstaken bij de provincies, en mogelijk in de toekomst bij regionale omgevingsdiensten, met wellicht aanvullend een centrale handhavingstaak richting de landelijk opererende verificateurs. Medewerkers van de ingestelde instantie, de NEA (de Nederlandse Emissieautoriteit), geven overigens inmiddels signalen af dat het systeem van handhaving nog verbeterd moet worden, met name EU wijd gezien, waarbij in het bijzonder de kwaliteit van de verificatie zorgen baart. ${ }^{154}$ In de EU is in feite gestart met een broeikasgasemissiehandelssysteem zonder een goed verankerd handhavingsysteem, terwijl bovendien de implementatietermijn absurd kort was. In de uit 27 lidstaten bestaande EU, waarbij voor elk bedrijf de hoeveelheid potentieel te verkopen emissierechten afhankelijk is van de rapportage over alle broeikasgasemissies door dat bedrijf in een jaar, is er gelet op de gebrekkige handhavingservaringen een aanzienlijk risico voor

153 Zie Rock Pring (2006).

154 Zie onder meer "Toezicht op emissies wordt volwassen", Handhaving $24^{e}$ jaargang oktober 2008, p22-25, p. 25, met het citaat "Het kan natuurlijk niet zo zijn dat een ton $\mathrm{CO}_{2}$ in Polen overeenkomt met anderhalf ton in Nederland" en "'Desondanks verwachten we niet dat alles op korte termijn is opgelost. Zoiets vergt tijd. Maar we hopen dat we aan het begin van de volgende periode (2013) een flinke stap vooruit hebben gezet". 
aantasting van de ijzeren regel dat alleen de besparing van een ton $\mathrm{CO}_{2}$ een emissierecht oplevert. Opvallend is dat de lidstaten vanwege de Europese richtlijn gedwongen moeten kiezen voor de figuur van een verificateur, terwijl eigenlijk een fundamentele afweging gemaakt zou moeten worden hoe deze figuur op doelmatige en effectieve wijze zou bijdragen aan handhaving. Het risico op gebreken, waarbij de private controleur, betaald door de gecontroleerde, op creatieve wijze normontduiking zou maskeren, is immers aanwezig. ${ }^{155}$ In het kader van het STEMprogramma is onlangs onderzoek gedaan naar het gebruik van conformiteitsbeoordelingen zoals certificering door private partijen bij de controle op de naleving van het milieurecht. Uit zo een onderzoek blijkt dat deze op zich interessante figuur van certificatieenverificatie,ookwel normconformiteitsbeoordelingen geheten, en die dus wel al voorkomt in het milieurecht, eigenlijk nog onvoldoende doordacht is. In dit onderzoek is aangegeven dat tal van juridische aspecten onderbelicht zijn gebleven, zoals de vraag of wel of niet sprake is of zou moeten zijn van een bestuursorgaan, en voor wie de door een verificateur verkregen informatie beschikbaar moet zijn. ${ }^{156}$ In het onderzoek naar normconformiteitsbeoordelingen hebben we bovendien geopperd dat er wellicht nieuwe modellen moeten worden ontwikkeld voor het verder gebruikmaken van certificateurs en verificateurs in het publiekrecht, zoals een doorbreking van de financiële relatie tussen controleur en gecontroleerde. Het belang van de verbetering van de handhaving van het broeikasgasemissiehandelssysteem voor bedrijven lijkt ook wel te zijn onderkend, omdat een van de nieuwe elementen van de recent aanvaarde herziening van het emissiehandelssysteem is dat er in een verordening regels zullen worden gesteld over de accreditatie van en toezicht op de verificateur. ${ }^{157}$ Het zal interessant zijn om te bezien en om mee te denken over de vraag hoe het functioneren van een verificateur in juridisch opzicht geregeld moet worden, en wat de verhouding en toegevoegde

155 Zo ook geopperd door Fiona Haines, Nancy Reichman (2008). Zie over de (opgelegde) figuur van de verificateur Marjan Peeters (2006a). Overigens is niet gezegd dat toezicht door bestuursorganen per definitie accurater zou zijn.

156 Joop De Boer, Richard Neerhof, Marjan Peeters (2009).

157 Europees Parlement (2008b), betreffende de voorgestelde wijziging van art. 15. 
waarde is van de verificateur ten opzichte van het met toezicht en handhaving belaste bestuursorgaan.

- Een ander fundamenteel punt betreft de vraag of het aanknopingspunt van regulering wel juist is gekozen. Een zeer revolutionair voorstel inzake het aanknopingspunt voor toedeling van rechten houdt in dat de emissierechten uitsluitend aan burgers zouden worden toegekend, waarbij de bedrijven de rechten rechtstreeks van de burgers zouden kopen. ${ }^{158}$ Meer realistisch is de gedachte dat het aanknopingspunt van emissiehandel niet moet liggen bij industrie, maar bij de winning van kolen, olie en gas.159 Het huidige systeem van broeikasgasemissiehandel faciliteert in feite het blijven gebruiken van kolen, waarbij bovendien het ondergronds opslaan van de $\mathrm{CO}_{2}$-emissie die afgevangen wordt bij kolenverbranding zal worden gefaciliteerd. Ook hieromtrent is in december 2008 overeenstemming bereikt over een juridisch kader voor $\mathrm{CO}_{2}$ opslag, een techniek die vooralsnog duur is en waarmee via proefprojecten nadere ervaring zal moeten worden opgedaan. ${ }^{160}$ Dergelijke grootschalige maatregelen, die andere problemen met zich meebrengen, zouden naar mijn idee met geduld bezien moeten worden. Er is nu een vlucht naar het vormgeven van een juridisch kader voor deze techniek, terwijl het onderzoek daarnaar maar bovenal een brede afweging tussen verschillende opties tot broeikasgasreductie en energievoorziening zijn tijd nodig heeft.

- De keuze van het aangrijpingspunt van regulering is voorts relevant in het licht van de uitbreiding van het broeikasgassysteem. Welke sectoren gaan onder broeikasgasemissiehandel vallen, en welke niet? Zo ja, zijn de condities om broeikasgasrechten dan te verkrijgen gelijk, of moet er juist verschil zijn? Het Hof van Justitie te Luxemburg geeft de Europese wetgever een grote mate van vrijheid bij dergelijke keuzes, hetgeen op 16 december 2008 bevestigd is in een uitspraak over een prejudiciële vraag over de broeikasgasemissiehandelsrichtlijn. ${ }^{161}$ Aan de orde was

158 Zoals kort besproken door het Environmental Audit Committee in Groot-Brittannië, zie Marjan Peeters (2008b).

159 Roy Op 't Veld (2008). Ook is voorgesteld om het aangrijpingspunt van regulering aan het begin van de keten van verspreiding neer te leggen, te denken valt aan mijnen, olieraffinaderijen: William Whitsell (2007) p. 458.

160 Europees Parlement (2008c).

161 HvJ EG C-127/07, datum uitspraak 16 december 2008. 
de mogelijke strijdigheid van de emissiehandelsrichtlijn met het gelijkheidsbeginsel doordat de staal- en ijzersector wel onder de reikwijdte van emissiehandel valt, en de aluminium en plasticindustrie niet, terwijl sprake is van deels substitueerbare producten. Het Hof, in lijn met eerdere jurisprudentie, erkent hier de ruime beoordelingsbevoegdheid op gebieden waar de gemeenschapswetgever politieke, economische en sociale keuzes moet maken en wanneer hij ingewikkelde beoordelingen moet doen. Voorts is er de mogelijkheid om bij ingewikkelde regelingen in etappen te werk te gaan. Het Hof komt tot het oordeel dat uit oogpunt van het beginsel van gelijke behandeling richtlijn $2003 / 87 /$ EG niet aantastbaar is voor zover er een verschil in toepasselijkheid is gemaakt. De vraag is in hoeverre niettemin in het nationale allocatieplan een evenwicht gezocht moet worden tussen enerzijds de positie van de onder het systeem vallende bedrijven en anderzijds hun concurrenten die onderhevig zijn aan nationaal (en Europees) recht, en in hoeverre de nationale rechter de uitvoeringsbesluiten van nationale bevoegde instanties wellicht indringender toetst. Niet uitgesloten is dat in dat kader nog een bijstelling had kunnen plaatsvinden, afhankelijk van de inhoud van de toepasselijke besluiten (in het nationale toewijzingsbesluit en in andere wetgeving). Deze uitspraak lijkt overigens ruimte te bieden voor de verschillen in benadering die in het nieuwe emissiehandelsregime als gevolg van de politieke onderhandelingen zijn gemaakt, althans bevestigt nog eens dat er een ruime mate van beoordelingsvrijheid is.

- De vorige vraag, het kiezen van het juiste aanknopingspunt voor regulering, is voorts relevant bij het verbinden van nationale emissiehandelssystemen. Bij het streven naar een mondiale koolstofmarkt, die gradueel kan ontstaan door een samenvoeging van verschillende systemen, is er behoefte aan harmonisering van de regels voor die emissiehandelssystemen. ${ }^{162}$ Immers, indien een van de systemen een zwakker handhavingsregime heeft, of een soepelere toewijzing van rechten, dan kan dat tot nadeligere posities leiden voor (deelnemers in) andere landen. Een half jaar nadat door de Commissie een drastische herziening van de broeikasgasemissiehandelsrichtlijn werd aangekondigd is de inschrijving op een project gestart ter financiering van

162 Janneke Bazelmans (2008). 
onderzoek naar onder meer de vormgevingsaspecten van emissiehandel. ${ }^{63}$ Dit onderzoek, waarvan de resultaten nu nog niet bekend zijn, zou staan in het teken van het verbinden van nationale of regionale emissiehandelssystemen. Dergelijke studies zijn nodig om te begrijpen hoe een regionale markt inderdaad verder verbonden kan worden met andere markten. In juridisch opzicht is daarbij bijzonder te zien hoe regelingen in verschillende landen geharmoniseerd zouden worden doordat men een emissierechtenmarkt wil creëren. Een bijzondere vorm van 'trading up', zou men kunnen stellen. ${ }^{164}$

- Tot slot zouden we ook in ruimere zin de keuze voor broeikasgasemissiehandel moeten doordenken. Door de Europese keuze voor dit marktconforme instrument, en door de verregaande centralisering die nu in de EU zal plaatsvinden, komt de rechter nauwelijks nog in beeld waar het gaat om de klimaatverplichtingen voor bedrijven. Waar in vergunningverlening de beslissing over de inhoud van de vergunning in Nederland door de Afdeling bestuursrechtspraak wordt getoetst, met de mogelijkheid om prejudiciële vragen te stellen als er onduidelijkheid heerst over de inhoud van een toepasselijke Europese norm, zien we bij emissiehandel dat de Europese instituties de belangrijkste regels stellen voor de grote bedrijven met broeikasgasemissies. Ik heb al wel gesteld dat de burger zich dubbel vervreemd zou kunnen voelen van de gekozen sturingsvorm: in de eerste plaats is het "Brussel" dat de belangrijke kaders stelt voor het EU wijde emissiehandelssysteem; en in de tweede plaats is het "de markt" die binnen dat kader besluit op welke plaats en tegen welke prijs de emissies zullen plaatsvinden. Zowel Brussel en de markt worden als tamelijk onzichtbare sturingsvormen gezien waar niet per definitie vertrouwen in bestaat. Dat is dan ook de reden dat ik heb betoogd dat het oude systeem van nationale allocatieplannen het voordeel had dat de besluitvorming over de verlening van de broeikasgasruimte in principe dichter bij de burger bleef, waarbij overigens onvoldoende is onderzocht in hoeverre inspraak en participatie bij de nationale besluitvorming nu daadwerkelijk heeft plaatsgevonden. Nu gekozen is voor centralisering van

163 Commission of the European Communities (2008e), Directorate-General for Environment, Open Call for Proposals International Climate Change, July 2008.

164 Naar David A. Vogel (1998). 
besluitvorming omtrent de Europese broeikasgashandel kan wellicht worden gedacht aan alternatieven om de burger toch betrokken te houden bij het klimaatbeleid, of althans betrokken burgers te faciliteren klimaatvriendelijke keuzes te maken en zo invulling te kunnen geven aan de per capita gedachte of carbon footprint. Hier kan met name worden gedacht aan het "labellen" van de koolstofuitstoot van producten. Indien je als consument zo min mogelijk wil bijdragen aan het klimaatprobleem, heb je immers informatie nodig over de klimaatuitstoot van een product of dienst om je afweging te maken. Uit de literatuur heb ik echter begrepen dat het opnemen van milieu-informatie in een label een ingewikkeld instrument is, dat zelfs tot perverse effecten kan leiden. ${ }^{165}$ Voorts zijn dergelijke benaderingen vanuit een internationaal handelsrechtelijk perspectief niet meteen eenvoudig uitvoerbaar. Niettemin ligt hier een interessante vraag wanneer een 'carbon label' op producten en diensten als instrument in aanvulling op broeikasgasemissiehandel voor bedrijven - zinvol en bruikbaar zou zijn.

De opmerkingen hierboven zijn enkele eerste waarnemingen over het gesloten akkoord inzake de wijziging van de richtlijn broeikasgasemissiehandel, het centrale klimaatbeleidsinstrument van de EU, en geven aan in welk perspectief ik dat verder wil gaan bestuderen. ${ }^{166}$

165 D. Bougherara et al. (2005).

166 De teksten zijn overigens nog niet formeel aanvaard door de Raad. 


\section{Aanvullende benaderingen}

39 Naast het krachtige instrument van wetgeving biedt het recht ook andere middelen om het klimaat te beschermen. Als het publiekrechtelijke kader niet geschikt is of tekortschiet bij het sturen van milieugedrag is het aansprakelijkheidsrecht van wezenlijk belang. Verdragspartijen vermijden zorgvuldig het element van aansprakelijkheid op te nemen in belangrijke overeenkomsten zoals het wereldwijde klimaatverdrag. ${ }^{167}$ Tegelijkertijd sluit het feit dat zo een verdrag gesloten is aansprakelijkheid niet uit.

40 Hetis echtergeen sinecure om een succesvolle aansprakelijkheidsactie te construeren voor dreigende klimaatschade. ${ }^{68}$ Hier liggen nog enkele precaire vragen, zoals hoe de causaliteit tussen de uitstoot van broeikasgassen en het effect op een bepaalde plaats (en tijd) kan worden geconstrueerd, en, in samenhang daarmee, hoe met meerdaderschap kan worden omgegaan.

41. De dreiging van aansprakelijkheid zou als een aanjager kunnen werken voor krachtige wetgeving of zelfstandige acties door emittenten, maar deze motor is op dit moment nog niet volledig geassembleerd. Hier lijkt vooral van belang dat er in de meest kansbare cases proefprocessen worden gestart. ${ }^{169}$ Het effect van het voeren van een discussie over het aansprakelijkheidsrecht moeten we niet onderschatten, aangezien de dreiging dat een bedrijf of overheid toch aansprakelijk zou kunnen zijn al als een stok achter de deur zou kunnen werken. Het is dan ook niet vreemd dat tijdens de vergadering van de Vereniging voor Milieurecht in november 2008 veel leden zich bereid hebben verklaard om in de werkgroep klimaatverandering en rechtsontwikkeling de mogelijkheden van klimaataansprakelijkheid verder te verkennen. Voor het succes daarvan lijkt het Amerikaanse Hooggerechtshof in zijn eerder genoemde uitspraak een belangrijke aanwijzing te hebben gegeven door te stellen dat er een eigen

167 Philippe Cullet (2007) p.166.

168 Zowel Michael Faure en André Nollkaemper, als Jaap Spier geven niettemin aan dat het instellen van succesvolle aansprakelijkheidsacties niet ondenkbaar is Zie voor een bespreking van kernaspecten van aansprakelijkheid in internationaal en nationaal perspectief Michael Faure en André Nollkaemper (2007), Jaap Spier (2007).

169 Marga Robesin, Kathleen Mertens (2009) en eerder Jaap Spier (2007). 
verantwoordelijkheid is om reducties te verwezenlijken, en dat deze niet afhankelijk mag worden gesteld van de vraag of anderen (andere landen) ook reducties nemen. ${ }^{70}$

42. Daarnaast duikt regelmatig de vraag op of het niet mogelijk is via unilaterale handelsmaatregelen binnenlandse sectoren te beschermen die klimaatmaatregelen moeten nemen. Een variant daarop zou zijn dat in een multilaterale klimaatovereenkomst handelsmaatregelen worden opgenomen jegens degenen die zich niet willen aansluiten en ook anderszins niet tot een effectief klimaatbeleid bereid zijn. Langzamerhand komen er in de literatuur aanwijzingen dat de inzet van het internationale handelsrecht tot de mogelijkheden moet behoren. ${ }^{71}$

43. Voorts werpt de klimaatverandering nieuwe vragen op in het kader van de mensenrechten. In toenemende mate wordt aandacht gevraagd voor het nieuwe fenomeen van klimaatvluchtelingen, die op dit moment een juridische bescherming ontberen in het internationale recht. ${ }^{172}$ In dit verband wil ik graag vermelden onder de indruk te zijn van het onderzoek en onderwijs van collega Brad Morse, verbonden aan de Universiteit van Ottawa, die al jaren de positie van de Inuit in Noord-Canada bestudeert en momenteel in zijn onderzoeksgroep de effecten van klimaatverandering bestudeert op de leefomstandigheden van deze groep, en zich bezighoudt met de vraag hoe vanuit het recht aan hun positie bescherming kan worden gegeven.

44. Een andere loot van het klimaatonderzoek betreft de vraag welke maatregelen nodig zijn voor aanpassing aan de negatieve effecten van klimaatverandering, zoals de verwachte zeespiegelstijging. De algemene term voor dit onderdeel van het klimaatbeleid luidt adaptatie: hoe kan de omgeving zich aanpassen aan de effecten van het klimaatbeleid, en welke juridische aspecten zijn hieraan verbonden? Daarbij hoort ook het vormgeven van hulp aan

170 Supreme Court USA, Massachusetts v Environmental Protection Agency 549 U.S. 497 (2007) (uitspraak van 2 april 2007).

171 W. Th. Douma (2008), Oren Perez (2006).

172 Paul G. Harris (2007), Angela Williams (2008); zie ook een uitgebreide literatuurlijst op http://www.glogov.org/images/doc/List\%200f\%20References\%20climate\%20refugees.pdf. 
ontwikkelingslanden, zoals het Adaptatiefonds dat is opgericht bij besluit van de partijen van het Kyoto Protocol en dat tijdens de klimaatconferentie te Poznan nader ingevuld is. ${ }^{173}$

Een kernvraag is wie nu eigenlijk verantwoordelijk is voor adaptatie, de overheid of private personen zelf? ${ }^{174}$ Inzake de plichten van de overheid spelen de mensenrechten een belangrijke rol, zoals art. 2 EVRM waarin het recht op leven is neergelegd en van waaruit een verplichting voor de overheid voortvloeit om de bevolking te beschermen tegen levensbedreigende omstandigheden. Door mensenrechtjuristen wordt inmiddels de aandacht gevestigd op het feit dat de klimaatproblematiek de verwezenlijking van mensenrechten zal beletten, en dat daarom overheidsoptreden nodig is. 175

45. Samen met collega Véronique Bruggeman heb ik in opdracht van het NWO de lastige vraag behandeld wat nu eigenlijk de taak van de overheid en de eigen verantwoordelijkheid van burgers is in het bijzondere geval van een abrupte op korte termijn plaatsvindende klimaatverandering. ${ }^{176}$ Samen met haar heb ik gezien dat ook in het veld van adaptatie interessante marktarrangementen kunnen ontstaan waarmee de private sector eigen oplossingen kan vinden voor economische schade, zoals weerderivaten en catastrofepolissen. Voor juristen geïnteresseerd in overheidssturing is het bij de vraag hoe we ons kunnen aanpassen aan klimaatverandering dan ook van belang te zien dat bepaalde arrangementen door de marktzelf worden ontwikkeld, zoals genoemde innovatieve verzekeringsproducten. ${ }^{77}$ Het overheidsbeleid kan er nu juist op zijn gericht om waar mogelijk zulk initiatief te laten nemen. Bepaalde maatregelen, zoals mogelijke schadevergoedingen waar verzekeringsmogelijkheden te kort

173 Zie artikel 12(8) Kyoto Protocol en de beslissing Decision 1/CMP3 zoals besloten te Bali in december 2007, zie http://unfccc.int/cooperation_and_support/financial_mechanism/adaptation_fund/items/3659.php.

174 Samuel Fankhauser e.a. (2008) stellen "Adaptation to climate change as a public policy challenge has only just emerged", p. 127.

$175 \operatorname{NJCM}(2008)$.

176 Véronique Bruggeman, Marjan Peeters (2008).

177 Met name in OESO verband wordt gewezen op de mogelijkheid om privaat initiatief te laten nemen om met klimaatschade om te gaan Samuel Fankhauser e.a. (2008), p. 126. 
schieten, ${ }^{178}$ en grootschalige infrastructurele en waterstaatkundige aanpassingen zullen door de overheid zelf geïnitieerd moeten worden. Het gaat daar om grootschalige projecten, waar de overheid initiatiefnemer en beslisser ('vergunningverlener') is. Juist hier is aandacht nodig voor juridische systemen die controle uitoefenen op deze besluitvorming, want het feit dat dergelijke mega-besluiten in handen zijn van de regering of andere (centrale) overheidsorganen wil niet zeggen dat deze besluiten per definitie de juiste zijn. Zo is bijvoorbeeld in de literatuur fundamentele kritiek uitgeoefend op het besluit tot aanpassing van de rivier de Maas na de overstromingen in 1993 en 1995..$^{179}$ Het vormgeven van dusdanige procedures dat besluitvorming over dergelijke grootschalige projecten zo goed mogelijk is, teneinde slechte of zelfs overbodige adaptatiemaatregelen te voorkomen, is absoluut nodig. Helaas moeten we constateren dat de overheid, die zelf een belangrijke initiatiefnemer is, juist onder de vlag van juridisering eerder tot versobering van waarborgen is geneigd. In een rechtsstaat zullen we echter een zekere mate van juridisering moeten accepteren, ${ }^{180} \mathrm{en} \mathrm{nu}$ eenmaal af en toe wat geduld moeten hebben met besluitvorming. Juist daar waar de overheid zelf de grootste belanghebbende is, zoals bij infrastructurele en waterstaatkundige projecten, is er bovendien het gevaar dat het recht in zekere zin naar de hand wordt gezet van de uitvoerders, en dat het belang van zorgvuldige besluitvorming en een evenwichtige belangenafweging gevaar loopt.

46. Een ander belangrijk onderdeel van het klimaatbeleid en daarmee ook van de klimaatwetgeving is de bevordering van duurzame energie. De omgevingswetgeving zal adequaat moeten worden ingericht om duurzame energie mogelijk te maken. Het recht dient daarbij de noodzakelijke procedures te verschaffen om de energietransitie en daarmee ook innovatieve energie-projecten te faciliteren, maar met bescherming van andere individuele en collectieve belangen. Het gaat daarbij bijvoorbeeld om de belangen van de omwonenden bij windmolens en natuurwaarden bij bouwen in zee. De nieuwe

178 Samuel Fankhauser e.a. (2008) p. 126.

179 Gerard van de Ven (1996).

180 Zie in deze zin diverse opinies op de studiedag "Juridisering in het Omgevingsrecht" van het Centrum voor Milieurecht op 18 december 2008 te Amsterdam; een bundel verschijnt in de loop van 2009. 
richtlijn duurzame energie regelt voor de EU als geheel dat in 2020 $20 \%$ hernieuwbare energie moet worden verwezenlijkt, en legt aan ons land een verplichting op dat in $202014 \%$ aandeel hernieuwbare energie zal zijn verwezenlijkt. ${ }^{81}$ Onder hernieuwbare energie wordt verstaan energie uit hernieuwbare niet-fossiele energiebronnen, zoals wind, zon, geothermische warmte, golfslag, getij, waterkracht, biomassa, stortgas, gas van rioolwaterzuiveringsinstallaties en biogassen. ${ }^{182}$ In het beleid inzake klimaatvriendelijke energie klinkt door dat eventuele onnodige juridische belemmeringen moeten worden weggehaald. ${ }^{183}$ Zo staat in het Nederlandse actieprogramma Schoon en Zuinig dat actie wordt ondernomen om belemmerende regelgeving voor duurzame energie aan te pakken; deze actie bevindt zich in een inventarisatiefase van wat nu eigenlijk belemmerende regelgeving is. ${ }^{184}$

47. Daarnaast is er in december 2008 een akkoord bereikt over een richtlijnvoorstel waarmee de uitstoot van broeikasgassen bij de opwekking van energie wordt tegengegaan, te weten de richtlijn voor $\mathrm{CO}_{2}$ afvang en opslag. ${ }^{185}$ De Nederlandse regering voorziet twee grote demonstratieprojecten voor $\mathrm{CO}_{2}$ afvang en opslag. ${ }^{186} \mathrm{Het}$ is duidelijk dat deze laatste voorziening een minder optimale keuze is vanuit milieuoogpunt dan vormen van hernieuwbare energie, aangezien de $\mathrm{CO}_{2}$ opslag per definitie leidt tot opslag van potentieel gevaarlijk gas onder de grond. Vanwege de mogelijke milieu- en

181 Commissie van de Europese Gemeenschappen, Voorstel voor een richtlijn van het Europees Parlement en de Raad ter bevordering van het gebruik van energie uit hernieuwbare bronnen, COM(2008)19 definitief, Brussel, 23 januari 2008.

182 Zie art. 2(a) van het richtlijnvoorstel.

183 Voorts committeert onze nationale overheid zich aan het overwinnen van onder meer planologische belemmeringen, zoals staat in het Sectorakkoord energie $2008-2020$. Sectorakkoord Energie 2008-2020: Convenant tussen Rijksoverheid en energiebranches in het kader van het werkprogramma Schoon en Zuinig, 28 oktober 2008, overwegingen. Bijlage bij kamerstuk 31209, nr. 43, Tweede Kamer.

184 Correspondentie met het ministerie van VROM in november 2008; zie ook het Actieprogramma schoon en zuinig, p. 43 en de genoemde knelpunten op p. 41 en 42 .

185 Commissie van de Europese Gemeenschappen, Voorstel voor een Richtlijn van het Europees Parlement en de Raad betreffende de geologische opslag van kooldioxide (en tot wijziging van diverse richtlijnen en een verordening) COM(2008)18 definitief, Brussel, 23 januari 2008.

186 Regeerakkoord Samen Werken Samen Leven, p. 34. Inmiddels zijn twee projecten bekendgemaakt, te weten bij Barendrecht en bij Geleen. 
veiligheidsrisico's is daarom de noodzaak van juridische regels ter voorkoming van schade duidelijk aanwezig. Ook bij de hernieuwbare vormen van energie zullen procedures en materiële normen nodig zijn om een zo goed mogelijke besluitvorming te bevorderen. Zo kunnen ook bij hernieuwbare energie individuele belangen in het geding zijn, zoals (vrees voor) potentiële gezondheidseffecten en verstoring van het privé- en gezinsleven vanwege bijvoorbeeld geluidshinder door windmolens. Daarnaast kan men denken aan een inbreuk op het recht op een ongestoord genot van eigendom door de nabije plaatsing van een windmolen. Voorts kunnen er milieu- en natuurbelangen in het geding zijn, zoals vogelschade door windmolens, grondwaterschade door warmte- en koude-opslag, en visschade door waterkrachtcentrales. Uiteraard kan bij bepaalde vormen van hernieuwbare energie, met name windenergie, ook het NIMBY effect optreden: er is serieuze oppositie waar te nemen bij windenergie op land, waar men in de eigen woonomgeving geen zicht wil hebben op windturbines. ${ }^{187}$ Het recht zal voor omgevingsingrepen zoals het verwezenlijken van hernieuwbare energie en het ondergronds opslaan van $\mathrm{CO}_{2}$ een besluitvormingskader dienen te bieden dat leidt tot efficiënte besluitvorming, waarbinnen natuur en milieu - in ruime zin geïnterpreteerd - en individuele belangen hun bescherming genieten. Die bescherming kan er uit bestaan dat bepaalde ruimtelijke of technische maatregelen genomen worden (zoals de precieze plaatsing van de windmolen, of de technische specificatie van het type windmolen), dat een financiële compensatie wordt betaald aan degenen die bijvoorbeeld de waarde van hun eigendom aangetast zien, en, in wellicht uitzonderlijke gevallen, een verbod op de voorgenomen activiteit. Interessant daarbij is de vraag welke vrijheid het bestuur wordt gelaten, welke procedurele rechten openstaan in het kader van deze besluitvorming, en in welke gevallen de rechter een besluit inzake omgevingsrechtelijke belangen onrechtmatig zou bevinden, en op welke grond dat zou zijn. ${ }^{188}$

187 Zie het OECD / IEA rapport (2008) dat wijst op het feit dat administratieve belemmeringen, en het NIMBY-effect, een effectieve realisatie van hernieuwbare energie belemmeren. Dit laat natuurlijk onverlet dat er juridische procedures nodig zijn om andere belangen dan duurzame energie een volwaardige plaats te geven, en dat waar nodig een afweging wordt gemaakt.

188 Zie hierover Marjan Peeters (2009). 


\section{Onderzoeksagenda}

49. Mijn onderzoek zal zich richten op het bouwen aan een pakket van overheidsinterventies in samenhang met door de markt genomen initiatieven die gericht zijn op de reductie van broeikasgassen, het realiseren van klimaatvriendelijke energie, het voorkomen van schade, en het vergoeden en herstellen van (onvermijdelijke) schade.

50. Vandaag staan we voor een grote uitdaging, te weten de vraag hoe we om kunnen gaan met het immense klimaatprobleem. Historisch besef van de uitdagingen die in het verleden door de mens zijn ontmoet en zijn overwonnen is daarbij naar mijn mening zeer vruchtbaar om juist ook de onzekere toekomst beter te kunnen begrijpen. We mogen naar mijn mening immers veel vertrouwen hebben in de innoviteit en technische capaciteiten van de mens. In 1898 werd in de New York Times verslag gedaan van de alarmerende voorspelling van de Britse hoogleraar en chemicus William Crookes dat er vanaf 1930 ernstige voedseltekorten zouden ontstaan, vanwege slechte graanopbrengst door sterk verarmde grond. ${ }^{89}$ De uitvinding van kunstmest heeft uiteindelijk redding gebracht, zij het dat later bleek dat deze kunstmest tot aanzienlijke milieuverontreiniging leidde die om beheersingsmaatregelen vroeg.

Een andere interessante historische kijk, ditmaal op kolenwinning die heden ten dage in een negatief daglicht staat vanwege de broeikasgasproblematiek, wordt gegeven door Bertus Aafjes. In een in opdracht van de Staatsmijnen in 1959 uitgegeven reportage over de kolenmijnen in Limburg heeft hij in opvallende termen van bewondering gesproken over deze energie-industrie, onder erkenning van de voordelen die het op dat moment opleverde voor

189 The New York Times (1898). Zie hierover Bertus Aafjes (1961) p. 105. William Crookes had berekend dat er niet genoeg stikstofmest op aarde was om de voor de mensheid nodige plantengroei gaande te houden. 
de maatschappij.190 Interessant is om te weten dat die cokes (kolen) nu juist gediend hebben voor het vervaardigen van kunstmest.191

51. De ontwikkelingen en innovaties gaan voort: eind vorig jaar is te Heerlen het Mijnwaterproject van start gegaan. ${ }^{192}$ Het is een uiterst vernieuwend project, het eerste proefproject in de wereld waarbij opgewarmd water uit de diepere lagen van het mijnenstelsel wordt gebruikt voor het op duurzame wijze verwarmen van gebouwen. ${ }^{193}$ Inderdaad, de ruimte die is ontstaan door kolenwinning, zoals bekend een oorzaak van broeikasgasemissies, wordt nu gebruikt voor klimaatvriendelijk energiegebruik. Lof in deze gaat naar de bedenker en initiatiefnemer, Elianne Demollin-Schneiders, werkzaam bij de gemeente Heerlen en tevens studente aan onze faculteit.194 Dit soort voorbeelden laten zien dat er belangrijke omwentelingen en uitvindingen in het verleden zijn gedaan. Er worden voorts bijzondere vondsten gedaan, waaronder de ontdekking van een schimmel in het Patagonische regenwoud die direct diesel kan maken uit plantenresten (om precies te zijn, uit cellulose). ${ }^{195}$ Voorts wordt gesproken over een mogelijke snelle ontwikkeling van elektrische auto's: in de staat Delaware in de VS wordt gewerkt aan een grootschalig plan om elektrische auto's op windenergie te laten rijden. ${ }^{196}$ Het idee is dat er tal van oplaadpunten in straten, bedrijfsterreinen en parkeergarage's komen: pieken aan elektriciteit worden opgeslagen in de in de auto's aanwezige batterijen en in

190 Aafjes plaatst de opvallende stelling: "De Limburgse mijnen hebben het Limburgse landschap niet wezenlijk aangetast, zij hebben er veeleer een nieuw element van schoonheid aan toegevoegd", p. 147.

191 Bertus Aafjes (1961), het betreft waterstof uit het gas van de cokesfabrieken, hetgeen tezamen met stikstof gefabriceerd werd tot ammoniak.

192 Zie http://www.minewaterproject.info/index.php. Zie over enkele juridische aspecten A.R. Neerhof en M. Peeters (2008).

193 Daarnaast vindt koelen plaats met mijnwater uit de hoger gelegen grondlagen.

194 Zie ook haar betoog over de verbetering van bouwregelgeving in het kader van energiebesparing: Elianne Demollin-Schneider (2008).

195 Elles Lalieu, 2008 (overige bronnen).

196 Ook Pier Vellinga wijst in zijn oratie op de voorziene snelle ontwikkeling voor elektrische auto's, en op de aansluiting van dat vervoer op windmolens. 
accu's, en bij een tekort aan windenergie wordt de opgeslagen elektriciteit weer afgegeven aan het net. ${ }^{97}$

Het zijn dergelijke revolutionaire (en nog nader te onderzoeken) projecten die de transitie naar hernieuwbare energie zullen moeten waarmaken. Het is de overheid die de prikkels en regels moet stellen die de betrokken partijen (de energiebedrijven, maar ook andere partijen zoals gemeentes die naar lokale vormen van hernieuwbare energie kunnen streven) aanzet of verplicht tot de benodigde transitie. Op het moment dat er strengere regelgeving of vergunningsvoorwaarden komen voor de productie van fossiele energie zal er gedwongen worden gezocht naar alternatieve energie (waaronder overigens ook nucleaire energie). ${ }^{198}$

De genoemde voorbeelden laten zien dat we wederom midden in het tij van een grote omwenteling staan, en dat zal tot nieuwe dimensies en oplossingen leiden die vaak van te voren juist niet te voorspellen zullen zijn. Het recht zal innovatie moeten stimuleren en faciliteren, en dat kan met emissiereductiedoelstellingen gecombineerd met handhavingsmechanismen, met gebruikmaking van marktconforme arrangementen om zo ruimte te geven aan nieuwe oplossingen. ${ }^{199}$ Ik wil met mijn onderzoek, samen met collegae, kunnen bijdragen aan het bouwen van een juridisch raamwerk dat bijdraagt aan de noodzakelijke gedragsaanpassingen en ruimte biedt aan belangrijke innovaties. ${ }^{200}$

52. De wetenschap analyseert overheidsoptreden en privaat ondernemen en tracht alternatieven te bieden voor bestaande patronen. We weten natuurlijk allemaal dat het overheidsoptreden via wetgeving niet een technocratisch gegeven is gericht op het beste resultaat, maar een politiek instrument. Juist daarom zijn andere geluiden, zowel

197 Informatie verkregen van professor David Hodas, Widener University, Wilmington, USA, dd 26.09.2008.

198 Interessant ook is om op dit punt de ontwikkelingen in de Verenigde Staten te volgen, alwaar vergunningverlening aan kolencentrales aan beroep wordt onderworpen.

199 Dit zal uiteraard niet altijd perfect werken, bekend is het voorbeeld dat eerst "laaghangend fruit" wordt geplukt (dus goedkoopste oplossingen worden genomen) alvorens tot werkelijke doorbraken over te gaan. Zie kritisch over vermogen tot technologische innovatie David M. Driessen (2003).

200 Marjan Peeters (2007d). 
van belangenorganisaties maar ook van onafhankelijke instituten een belangrijk tegenwicht aan de politieke besluitvorming over wetgeving. We zien ondertussen dat universiteiten steeds meer afhankelijk worden van projectgelden van externe financiers. We moeten erg kien blijven op de voor-en nadelen van deze marktgerichte ontwikkeling. Ik heb $u$ het voorbeeld genoemd van de kritiek op het Stern rapport: Nordhaus stelt dat dit rapport gelezen moet worden als een politiek rapport. Ook in eigen land is er alle noodzaak om te letten op de vraag welke beweegredenen of financiering een rol kunnen spelen bij de uitkomsten van onderzoek. Er zijn belangrijke voordelen aan het verkrijgen van externe onderzoeksopdrachten vanuit de tweede lijn en ook de derde lijn. Tegelijkertijd is het van belang dat er goede afspraken zijn over de onafhankelijkheid van het onderzoek, en dat ook qua universitair beleid de wetenschappers altijd een eigen ruimte wordt gegund waar vrij van opdrachtgevers onderzoek kan worden gedaan.

53. Interessant zou ook zijn om de financiering van het klimaatonderzoek in Nederland nader te analyseren. De kracht van geld voor de bepaling van de onderzoeksagenda kan niet worden onderschat. Zo wordt in Nederland een grote som geld ter beschikking gesteld voor het doen van onderzoek naar adaptatie aan klimaatverandering, met een zware focus op adaptatie in ons eigen land. Het aanpassen aan de gevolgen van klimaatverandering is inderdaad een zeer belangrijk thema, waarop belangrijk onderzoek moet worden gedaan. Ik ben zelf echter kritisch over de opvatting van de Wetenschappelijke Raad voor het Regeringsbeleid dat Nederland meer zou moeten inzetten op adaptatie in plaats van mitigatie. ${ }^{201}$ Indien dit standpunt wordt vertaald in de financiering van de agenda van de Nederlandse klimaatonderzoekers betekent het dat er wellicht minder ruimte is voor innovatief onderzoek inzake de terugdringing van broeikasgassen. Dit is een effect waarvoor mijns inziens gewaakt moet worden. Ook hier kan een vrijere rol van de wetenschapper, een wetenschapper dus die ook los van externe onderzoeksgelden zijn onderzoek kan bepalen, veel vruchten afwerpen.

54. Daarnaast blijft het van belang dat bij de verdeling van onderzoeksgelden, bijvoorbeeld bij het instellen van een commissie 
voor het doen van een voorstel van de beveiliging van Nederland tegen overstromingsgevaar, voldoende ruimte beschikbaar is om ook andere argumenten te laten klinken. Dat is immers de kern van de wetenschap, we zoeken naar een vorm van waarheid of naar een optimale benadering door onderzoek, debat en tegenspraak. We ontmoeten daarbij veel onzekerheden, juist ook op een terrein als klimaatverandering en de vraag hoe de overheid daarin kan sturen. Vanwege de vele belangen die daarin een rol spelen blijft het doen van onafhankelijk wetenschappelijk onderzoek en een wetenschappelijk debat, een groot goed. Ik ben erg blij dat ik daarin in mijn nieuwe functie mag gaan bijdragen en zal daar gaarne mijn energie voor inzetten. 


\section{Slotwoord}

55. Mijnheer de Rector Magnificus, dames en heren, aan het einde van deze rede wil ik nog enkele woorden van dank uitspreken.

Leden van het College van Bestuur van deze Universiteit, het College van toezicht van de leerstoel en het bestuur van de Faculteit der Rechtsgeleerdheid, ik dank $u$ zeer voor het aan mij gegeven vertrouwen om deze bijzondere leeropdracht te vervullen. Ik aanvaard bij deze dit ambt dan ook gaarne.

Collega's van de capaciteitsgroep publiekrecht en van Metro, collega's van de ius commune onderzoeksgroep grensoverschrijdend milieurecht, collega's van de faculteit en collega's van andere faculteiten: het milieurecht is niet goed in te delen in één vakgebied, en ik zweef dan ook regelmatig uit naar verschillende gebieden, zoals zelfs het consumentenrecht en naar gebieden buiten het recht. Ik zie dan ook uit naar samenwerking met collegae van allerlei disciplines, zowel binnen als buiten onze faculteit.

Zeer gewaardeerde studenten, tijdens de uitreiking van mijn propedeuse diploma kreeg ik van wijlen professor Deelen een prachtige toespraak over wat een studie je kan opleveren. De boodschap was om vooral met weelde te studeren, en ik hoop dat ik jullie in deze geest verder kennis kan laten maken met het recht. Die weelde zit hem er wat mij betreft in om na te denken over hoe het recht behulpzaam kan zijn bij maatschappelijke ontwikkelingen en problemen.202 $\mathrm{k}$ hoop dat jullie met mij mee willen denken over de noodzakelijke veranderingen in het recht, waarbij ik hoop dat onze faculteit er in zal slagen om het onderwijs en onderzoek nog meer met elkaar in verbinding te brengen.

Voorts spreek ik mijn waardering uit voor mijn collega's op het milieurechtelijk terrein, in binnen- en buitenland, en ik zie uit naar het verdere debat over de vormgeving van het milieurecht.

202 Hoogleraar internationaal privaatrecht, en collega van de reeds vermelde hoogleraar Schoordijk. Het is bijzonder te zien dat anno 2008 door Schoordijk in deze geest verder wordt gegaan, waar hij filosofeert over de relatie tussen recht en kunst en voorts betoogt: "Gevoel voor een steeds wisselend cultuurbeeld verraadt schoonheid". 
Bijzonder vereerd ben ik met de aanwezigheid vandaag van Ben Boer, emeritus-hoogleraar van Sydney Law School. Professor Ben Boer is stimulator van de wereldwijde Academy of Environmental law met inmiddels meer dan 100 universiteiten als lid, waaronder 5 Nederlandse universiteiten. ${ }^{203}$

In het bijzonder wil ik het woord richten tot twee collegae van onze eigen faculteit die voor mij van grote betekenis zijn.

In de eerste plaats is dat Michael Faure. Michael, je belde mij op een maandagochtend in 2000, en zei dat ik snel naar een vacature bij de UM moest komen. Ik wilde dat al wel doen, en na jouw telefoontje deed ik dat met nog meer plezier. Ik wist immers dat jij een sterke interesse hebt voor de vraag hoe in het milieurecht gebruik kan worden gemaakt van economische prikkels. Jij bekleedt zonder twijfel en om meerdere redenen een zeer unieke positie in het Nederlandse en in het internationale milieurecht, en het is mooi om te zien hoe je carrière immer stijgt, met bijzondere uitnodigingen vanuit de Verenigde Staten en eigenlijk alle werelddelen die er zijn. Je hebt me in vrijheid in hoog tempo veel laten zien en laten meemaken, en ik ben je daar bijzonder dankbaar voor.

In de tweede plaats een woord van dank aan Ellen Vos, hoogleraar Europees recht aan onze faculteit. Ellen, als alle vrouwelijke hoogleraren andere vrouwen net zo een zetje weten te geven zoals jij dat bij mij hebt gedaan dan zal de academische wereld heus in evenwicht komen. Het is boeiend om te zien hoe jij zaken weet los te trekken, hoe initiërend je bent, zowel op wetenschappelijk terrein, maar ook op organisatorisch vlak. De workshops die je organiseert zijn inspirerend, je netwerk is fantastisch, en ook jij durft het aan om de grenzen van het recht te verkennen en erover heen te stappen. Ik verheug me op de verdere samenwerking met jou, en het is de fascinatie voor onzekerheid die ons blijft verbinden.

De laatste woorden van mijn rede gaan naar mijn familie, een kleine samenleving bestaande uit een combinatie van ouders, schoonouders, broer, schoonbroers, zeven 'schone zussen' en neefjes en nichtjes. In zo een 'samenlevinkje' hebben we geen recht 
en handel nodig, maar liefde, vertrouwen en steun, en bovenal veel respect en vrijheid voor elkaar.

Lieve Jitse, Lieve Sjoerd. Het is zo mooi om met jullie allerlei dingen te beleven en te ontdekken, of het nu de dieren in de tuin zijn, een optreden van Lenny, of een fietsroute nog verder dan Parijs of hoger dan Col de Fourtou. Jullie ontwikkeling is al zo individueel, dat is mooi. Grijp jullie kansen, ik zal het graag volgen en jullie waar nodig steunen.

Tot slot René, mijn lief, al voor zo lang. We herinneren ons nog de mystieke sfeer in d'n Ingel, waardoor voor ons de dag vóór Valentijnsdag zo speciaal is. Heel anders dan recht en sturing zijn voor jou vooral ongeregisseerde momenten belangrijk, en ik hoop er nog veel met jou te kunnen beleven.

Ik heb gezegd. 


\section{Literatuur}

Aafjes, Bertus (1961), Het Troje van het Carboon, uitgave van de Staatsmijnen in Limburg, tweede druk 1961 (oorspronkelijke druk 1959).

Ahmad, Nadim en Andrew Wyckoff (2003), Carbon Dioxide Emissions Embodied in International Trade of Goods, OESO, STI Working Paper 2003/15.

Ahmad, Nadim (2004), A Framework for Estimating Carbon Dioxide Emissions Embodied in International Trade of Goods, in: OECD, Measuring Sustainable Development.

Aldy, Joseph E., Robert N. Stavins (eds.) (2007), Architectures for Agreement. Addressing Global Climate Change in the Post-Kyoto World, Cambridge University Press.

Baldwin, Robert (2008), Regulation Lite: The Rise of Emissions Trading, Law Society Economy Working papers, www.lse.ac.uk/collections/law/wps/wps.htm en http://ssrn.com/abstract=1091784.

Bazelmans, Janneke (2008), Connecting the EU ETS to other emissions trading systems, in: M.G. Faure, M. Peeters (eds.) (2008), Climate Change and European Emissions Trading: Lessons for Theory and Practice, Edward Elgar.

Best, Aaron, Daniel Blobel, Sandra Cavalieri, Stefan Giljum, Mark Hammer, Stephan Lutter, Craig Simmons, Kevin Lewi (2008), Potential of the Ecological Footprint for monitoring environmental impacts from natural resource use, Report to the European Commission, DG Environment.

Biermann, F. (2005), Between the USA and the South: strategic choices for European climate policy, Climate Policy 5: 273-290.

Bluemel, Erik B. (2008), Regional regulatory initiatives addressing GHG leakage in the USA, in: M.G. Faure, M. Peeters (eds.) (2008) Climate Change and European Emissions Trading: Lessons for Theory and Practice, Edward Elgar.

Bohne, Eberhard (2006), The Quest for Environmental Regulatory Integration in the European Union, Kluwer Law International.

Botzen, W.J.W., J.M. Gowdy, J.C.J.M. van den Bergh (2008), Cumulative CO2 emissions: shifting international responsibilities for climate debt, 8 Climate Policy (issue 6) p. 569-576. 
Bougherara, D. et al. (2005), Can labelling policies do more harm than good? Analysis applied to environmental labelling schemes, European Journal of Law and Economics, 19: 5-16.

Brenninkmeijer, Alex (2008), Een mediaombudsman, NJB 23-05-2008, afl. 21: 1271.

Bressers, J.Th. (1983), Beleidseffectiviteit en waterkwaliteitsbeleid, dissertatie Enschede.

Bruggeman, Véronique, Marjan Peeters (2008), Exploring governmental and victim responsibilities in view of abrupt climate change in North-Western Europe, in: J.C.M. Van den Bergh, A.J. Dietz, C.J. Jepma, F. Langeweg (ed.), (2008) What if... abrupt and extreme climate change?, Netherlands Organisation for Scientific Research (NWO), The Hague, p. 7-44.

Chayes, A. en Chayes, A.H. (1995), The New Sovereignty: Compliance With International Regulatory Agreements, Harvard University Press.

Coglianese, Cary en Jocelyn D’Ambrosio (2008), Policymaking under Pressure: The Perils of Incremental Responses to Climate Change: Connecticut Law Review, beschikbaar via SSRN: http://ssrn.com/abstract=1151445.

Cullet, Philippe (2007), Liability and redress for human induced global warming: towards an international regime, Stanford Journal of International Law and Stanford Environmental Law Journal, Symposium issue: Climate Change Risk (vol. 26A/23A), 2007: 99-121.

Dales, J.H. (1968), Pollution, Property and Prices, An essay in Policy-making and Economics, republished in 2002 by Edward Elgar.

De Boer, Joop, Richard Neerhof, Marjan Peeters (2009), De rol van conformiteitsbeoordelingen bij de handhaving van het milieurecht, te verkrijgen via www. evaluatiemilieuwetgeving.nl

De Smedt, Kristel (2007), Environmental Liability in a Federal System. A Law and Economics Analysis, dissertatie Maastricht.

Demollin-Schneiders, Elianne (2008) CO2-emissiereductie in de bouw, in: Tijdschrift voor Milieu en Recht, afl. 8: 495-497.

Den Elzen, M.G.J., M.M. Berk, P. Lucas (2004), Simplified Multi-Stage and Per Capita

Convergence: an analysis of two climate regimes for differentiation of commitments, RIVM report 728001027/2004. 
Driessen, David M. (2003), The Economic Dynamics of Environmental Law, Massachusetts Institute of Technology.

Douma, W.Th. (2008), Handelsbeperkingen ten behoeve van klimaat in het licht van het internationale handelsrecht: realistische optie of FAIRytale? in: Tijdschrift voor Milieu en Recht, afl. 7: 414-420.

Environmental Defense Fund (2008), Reducing emissions from forest degradation in developing countries, implications for the carbon market.

Europees milieu-agentschap (2008a), EEA Technical report No 9/2008, NEC Directive status report 2007, Reporting by the Member States under Directive 2001/81/EC of the European Parliament and of the Council of 23 October 2001 on national emission ceilings for certain atmospheric pollutants, http://reports.eea. europa.eu/technical_report_2008_9/en/NEC_Tech-9-2008_final.pdf.

Europees milieu-agentschap (2008b) Greenhouse gas emission trends and projections in Europe 2008, EEA report no 5 / 2008.

Fankhauser, Samuel, Shardul Agrawala, David Hanrahan, Gregory Pope, Jerry Skees, Chris Stephens, Shamina Yasmine, (2008), Economic and Policy Instruments to Promote Adaptation, in: Shardul Agrawala, Samuel Fankhauser (eds.) (2008), Economic aspects of adaptation to climate change, OECD.

Faure, M.G., en J.G.J. Lefevere (1996), The Draft Directive on Integrated Pollution Prevention and Control: an Economic Perspective, European Environmental Law Review 5: 112-122.

Faure, Michael en André Nollkaemper (2007), International Liability as an Instrument to Prevent and Compensate for Climate Change, Stanford Journal of International Law and Stanford Environmental Law Journal, Symposium issue: Climate Change Risk (vol. 26A/23A), 2007: 123-179

Faure, Michael, Marjan Peeters, Andri Wibisana (2006), Economic instruments: suited to developing countries?, in: Elaborating on integration of environmental legislation: the case of Indonesia, in: Michael Faure, Nicole Niessen (eds.), Environmental Law in Development; Lessons from the Indonesian Experience, Edward Elgar, p. 218-284.

Faure, Michael, Marjan Peeters (eds.) (2008), Climate Change and European Emissions Trading: Lessons for Theory and Practice, Edward Elgar. 
Fowler, Rob (2008), The role of marine "forests" and soils as carbon sinks: enhanced bio-sequestration as a mitigation strategy, paper gepresenteerd tijdens IUCN Academy of Environmental Law congres Climate Law in developing countries post 2012: North and South Perspectives, wordt in 2009 in congresboek gepubliceerd bij Edward Elgar (zie www.iucnael.org).

Frankel, Jeffrey (2007), Formulas for quantitative targets, in: Joseph E. Aldy, Robert N. Stavins (eds.) (2007), Architectures for Agreement. Addressing Global Climate Change in the Post-Kyoto World, Cambridge University Press.

Friman, Mathias, Björn-Ola Linnér (2008), Technology obscuring equity: historical responsibility in UNFCCC negotiations, in: Climate Policy 8: 339-354.

Fry, Ian (2008), Reducing Emissions from Deforestation and Forest Degradation: Opportunities and Pitfalls in Developing a New Legal Regime, in: Review of European Community \& International Environmental Law, vol. 17, issue 2.

Gupta, Joyeeta (2001), Our simmering planet, Zed books Ltd.

Gupta, Joyeeta (2006), Good governance and climate change: recommendations from a North-South perspective, in: Marjan Peeters en Kurt Deketelaere (eds.) (2006), EU Climate Change Policy: The Challenge of New Regulatory Initiatives, Edward Elgar.

Gupta, Joyeeta (2007), Beyond Graduation and Deepening: towards cosmopolitan scholarship, in: Joseph E. Aldy, Robert N. Stavins (eds.), Architectures for Agreement. Addressing Global Climate Change in the Post-Kyoto World, Cambridge University Press.

Haines, Fiona, Nancy Reichman (2008), The Problem That is Global Warming: Introduction, Law \& Policy vol. 30, no 4.

Harris, Paul G. (2007), Sharing the burdens of global climate change: international equity and justice in European policy, in: Paul G. Harris (ed.), Europe and Global Climate Change, Edward Elgar.

Harris, Paul G. (2008), Climate Change and Global Citizenship, in: Law \& Policy, vol. 30 , no. 4 .

Houghton, J.T. (2004), Global warming, the complete briefing, 3rd edition, Cambridge University Press.

Hovi, Jon, Bjart Holtsmark (2006), Cap-and-trade or carbon taxes? The feasibility of enforcement and the effects of non-compliance, International Environmental Agreements 6: 137-155. 
Huitema, Dave, Nicole Niessen, Marjan Peeters (2006), Onzekere risico's. Buitenlandse inspiratie voor besluitvorming in Nederland, STEM rapport $\mathrm{nr}$ 2006/5 : www.evaluatiemilieuwetgeving.nl.

Intergovernmental Panel on Climate Change (2007), Fourth Assessment Report, http://www.ipcc.ch/ipccreports/ar4-syr.htm.

International Energy Agency, World energy Outlook 2008, Executive summary, http://www.iea.org/Textbase/npsum/WEO2008SUM.pdf

Kallbekken, Steffen (2007), Why the CDM will reduce carbon leakage, Climate Policy 7: 187-211.

Kerr, Tom (2007), Voluntary Climate Change Efforts, in: Gerrard, Michael B. (ed.) (2007), Global Climate Change and U.S. Law, American Bar Association, p. 591626.

Krämer, Ludwig (2006), Statistics on Environmental Judgments by the EC Court of Justice, Journal of Environmental Law, vol 18 No 3: 407-421

Koopmans, T. (1970), De rol van de wetgever, in: Honderd jaar rechtsleven, Jubileumboek Nederlandse Juristen Vereniging, Zwolle 1970, p. 1-15.

Lammers, J.G. (2007), Billijkheid in het internationale milieurecht en de speciale positie van ontwikkelingslanden, afscheidsrede aan de Universiteit van Amsterdam, 11 april 2007.

Leeuw, Frans L. (2008), Gedragsmechanismen achter overheidsinterventies en rechtsregels, oratie Maastricht, 23 mei 2008.

Linares, Pedro, Francisco Javier Santos, Mariano Ventosa (2008), Coordination of carbon reduction and renewable energy support policies, Climate Policy 8: p. 377-394.

McMaster, Peter (2008), Climate Change-Statutory Duty or Pious Hope? Journal of Environmental Law, 20:1, p. 115-119.

MDW-werkgroep (2000), Verhandelbare rechten, Verhandelbare rechten Fase II Ingrijpen en compenseren?

Mertens, Kathleen, en Marga Robesin (2009), Aansprakelijkheid voor schade door klimaatverandering, in: uitgave Vereniging voor Milieurecht, onder redactie van $\mathrm{N}$. Teesing, Klimaatverandering en rechtsontwikkeling anno 2008, Boom juridische uitgevers. 
Michaelowa, Alex, (2007), Graduation and Deepening, in: Joseph E. Aldy, Robert N. Stavins (eds.) (2007), Architectures for Agreement. Addressing Global Climate Change in the Post-Kyoto World, Cambridge University Press.

Milieu en Natuur Planbureau (2007), Nederland en een duurzame wereld, Armoede, klimaat en biodiversiteit, Tweede Duurzaamheidsverkenning, Samenvatting xv, 2007.

Montesquieu (1748), Over de geest van de wetten (vertaling: 2006, door Jeanne Holierhoek), Uitgeverij Boom.

Nash, Jonathan Remy (2000), Too much market? Conflict between tradable pollution allowances and the "polluter pays" principle, Harvard Environmental Law Review, vol. 24: 465-535.

Netherlands Environmental Assessment Agency (2008), Consequences of the European Policy Package on Climate and Energy, zie www.mnp.nl.

NJCM (2008), 2008 OHCHR study, Climate Change and Human Rights, Stakeholder input by NJCM, Dutch Section of the International Commission of Jurists.

Nordhaus, William D. (2007), A review of the Stern Review on the Economics of Climate Change, Journal of Economic Literature, vol. XLV: 686-702.

OECD (2008), Environmental Outlook to 2030, Summary in English, OECD Outlook 2008, http://www.oecd.org/dataoecd/29/33/40200582.pdf.

OECD / International Energy Agency (2008), Deploying Renewables, Principles for Effective Policies.

Oosterhuis, Frans, Marjan Peeters en Rosa Uylenburg (2007), Het beoordelingskader van de IPPC-richtlijn: Implementatie, Interpretatie en toepassing, STEM project rapport nr 2006/5: www.evaluatiemilieuwetgeving.nl

Opschoor, Hans (2000), The Ecological footprint: measuring rod or metaphor? Ecological Economics 32: 363-365.

Page, Edward A. (2006), Climate Change, Justice and Future Generations, Edward Elgar.

Peeters, Marjan (1992), Marktconform milieurecht? Een rechtsvergelijkende studie naar de verhandelbaarheid van vervuilingsrechten, dissertatie Tilburg, W.E.J. Tjeenk Willink. 
Peeters, Marjan, en Kurt Deketelaere (eds.) (2006), EU Climate Change Policy: The Challenge of New Regulatory Initiatives, Edward Elgar.

Peeters, Marjan (2006a), Inspection and market-based regulation through emissions trading: the striking reliance on self-monitoring, self-reporting and verification, Utrecht Law Review, Volume 2, Issue 1 (http://www.uu.nl/uupublish/homerechtsgeleer/onderzoek/ utrechtlawreview/38361main.html), http://ssrn.com/abstract=991293.

Peeters, Marjan (2006b), Boekbespreking:WRR rapport: Klimaatstrategie - tussen ambitie en realisme (rapporten aan de regering nr. 46), in: Tijdschrift voor Milieu en Recht, afl. 9: p. 553.

Peeters, Marjan (2006c), Enforcement of the EU greenhouse gas emissions trading scheme, in: K. Deketelaere en M. Peeters (eds.) (2006) EU Climate Change Policy: The Challenge of New Regulatory Initiatives, Edward Elgar, p. 169-187.

Peeters, Marjan (2007a), EU Climate Change Policy: Critical Issues and Challenges for the future, International Yearbook of Environmental Law, Oxford University Press vol. 16-2005: p. 179-210.

Peeters, Marjan (2007b), Broeikasgasemissiehandel in Europa: op zoek naar een optimale verdelingsmethode, Nederlands Juristenblad 2007 nr. 45/46: 2893-2902.

Peeters, Marjan (2007c), Hooggerechtshof keert het tij, Tijdschrift voor Milieu en Recht, afl. 5: 261.

Peeters, Marjan (2007d), De VMR uitgedaagd door klimaatverandering: een open vizier voor innovatieve voorstellen, in: N. Teesing (red.) Klimaatverandering en de rol van het milieurecht, Publicatie van de Vereniging voor Milieurecht, Boom juridische uitgevers, p. 93-100.

Peeters, Marjan (2008a), Wie regeert in 2050? Tijdschrift voor Milieu en Recht, 2008, afl. 7: p. 413.

Peeters, Marjan (2008b), Personal Tradable Carbon Allowances, paper to the conference Poverty Alleviation and Environmental Law, IUCN Academy of Environmental Law Colloquium 2008, Mexico City, Mexico, (beschikbaar bij auteur).

Peeters, Marjan (2008c), The joint governance of transboundary river basins: some observations on the role of law. In M. Faure \& Y. Song (eds.) (2008), China and International Environmental Liability. Legal Remedies for Transboundary Pollution, Edward Elgar (pp. 192-224), Edward Elgar. 
Peeters, Marjan (2008d), Legislative Choices and Legal Values: Considerations on the further design of the European Greenhouse Gas Emissions Trading Scheme from a viewpoint of democratic accountability, in: M.G. Faure, M. Peeters (eds.), Climate Change and European Emissions Trading: Lessons for Theory and Practice, Edward Elgar 2008.

Peeters, Marjan (2009a), Noodzakelijke procedures voor duurzame energie, bijdrage aan de bundel Juridisering in het milieurecht van de gelijknamige studiedag van het Centrum voor Milieurecht, Universiteit van Amsterdam, gehouden op 18 december 2008 (publicatie verschijnt in 2009).

Peeters, Marjan (2009b),Vrijwillige broeikasgascompensaties door burgers en de noodzakelijke rol van de overheid, in: Teesing (red.) (2009) Klimaatverandering en rechtsontwikkeling anno 2008, Publicatie van de Vereniging voor Milieurecht, Boom juridische uitgevers.

Perez, Oren (2006), International Trade Law and the Environment, in: Benjamin J. Richardson, Stepan Wood (eds.) (2006), Environmental Law for Sustainability, The Osgoode Readers, Hart Publishing.

Pring, George (Rock) (2006), A decade of emissions trading in the USA: Experiences and observations for the EU, in: Marjan Peeters en Kurt Deketelaere (eds) (2006), EU Climate Change Policy. The challenge of new regulatory initiatives, Edward Elgar, p. 188-204.

Regieorgaan energietransitie (2008), Duurzame energie in een nieuwe economische orde.

Schelling, Thomas (2007), Epilogue, in: Joseph E. Aldy, Robert N. Stavins (eds.) (2007), Architectures for Agreement. Adressing Global Climate Change in the Post-Kyoto World, Cambridge University Press.

Schoordijk, H.C.F. (2008), Het recht moeten wij niet denken als een systeem vooraleer wij er systeem in gebracht hebben, Nederlands Juristenblad, afl. 28: 1721-1723.

Skea, Jim, Shuzo Nishioka (2008), Policies and practices for a low-carbon society, Climate Policy 8: 5-16.

Singer, S. Fred (2008), Nature, Not Human Activity Rules the Climate, Science and Environmental Policy Project, http://heartland.temp.siteexecutive.com/ pdf/22835.pdf.

Smith, Jeffrey A. (2007), Massachusetts v EPA: The Way Forward on Climate Change Regulation in the US, Environmental Liability, vol. 3: 127-132. 
Solomon, Lawrence (2008), The Deniers, Richard Vigilante Books.

Spier, Jaap (2007), Civielrechtelijke aansprakelijkheid voor klimaatverandering, doemscenario's voor onverantwoordelijke bedrijven en overheden, in: N. Teesing (red.) (2007), Klimaatverandering en de rol van het milieurecht, Boom Juridische uitgevers.

Spier, Jaap (2008), Het WRR-rapport Onzekere veiligheid: een welkome stap voorwaarts, Essay, NJB 14-11-2008: 2521-2525.

Stern, Nicholas (2007), The Economics of Climate Change: The Stern Review, Cambridge, UK: Cambridge University Press, online via http://www.hm-treasury. gov.uk/sternreview_index.htm. (executive summary long) (rapport is bekendgemaakt in oktober 2006).

Stewart, Richard B. en Jonathan B. Wiener (2003), Reconstructing Climate Policy, The AEI Press.

Strachan, Neil, Tim Foxon, Junichi Fujino (2008), Policy implications from the lowcarbon society (LCS) modelling project, Climate Policy 8: 17-29.

Streck, Charlotte, Jolene Lin (2008), Making Markets Work: A Review of CDM Performance and the Need for Reform, European Journal of International Law 19(2): 409-442.

Szolgayova, J., S. Fuss, M. Obersteiner (2008), Assessing the effects of $\mathrm{CO}_{2}$ price caps on electricity investments - a real options analysis, Energy Policy 36(10): 3974-3981.

Teuben, Reinske (2005), Verhandelbare emissierechten. Juridische aspecten van emissiehandel voor $\mathrm{CO}_{2}$ in Nederland en de Europese Unie, diss. Utrecht.

Tietenberg, T.H. (2006), Emissions Trading, Principles and Practice, second edition, Resources for the Future.

Van de Ven, Gerard (1996), The Netherlands and its rivers, Tijdschrift voor Economische en Sociale Geografie 87 (4):364-370.

Van den Bergh, J.C.M., A.J. Dietz, C.J. Jepma, F. Langeweg (eds.) (2008), What if... abrupt and extreme climate change?, Netherlands Organisation for Scientific Research, The Hague, October 2008.

Van Gestel, Rob (2008), Wetgeven is vooruitzien, oratie Tilburg 2008.

Van Ommeren F.J. (2004), Schaarse vergunningen. De verdeling van schaarse vergunningen als onderdeel van het algemene bestuursrecht, oratie VU, Kluwer. 
Van Kolfschoten, Thijs (2008), Het is een kwestie van kiezen, oratie Universiteit Leiden, 11 januari 2008, https://openaccess.leidenuniv.nl/bitstream/1887/13019/10ratie+Van+Kolfschote n.pdf

Victor, David G. (2001), The Collapse of the Kyoto Protocol, Princeton University Press.

Victor, David G. (2007), Fragmented carbon markets and reluctant nations: implications for the design of effective architectures, in: Joseph E. Aldy, Robert N. Stavins (eds.) (2007), Architectures for Agreement. Addressing Global Climate Change in the Post-Kyoto World, Cambridge University Press

United Nations Development Programme (2007), Human Development Report $2007 / 2008$.

Vellinga, Pier (2008), Hoogtij in de Delta, oratie Wageningen UR, 16 oktober 2008.

Verhey, L.F.M. (red.) (2003), Op zoek naar kwaliteit. Een onderzoek naar de toepassing en operationalisering van wetgevingskwaliteitseisen, SDU Den Haag.

Verschuuren, J.M. (2006), Fundament onder het omgevingsrecht, Een selectie uit het werk van Prof. mr. P.C. Gilhuis, Wolf Legal Publishers.

VROM Raad (1999), Mondiale duurzaamheid en de ecologische voetafdruk, Advies 016.

Vogel, David A. (1998), Trading up, Consumer and Environmental Regulation in a Global Economy, Harvard University Press.

Wang, Tao, Jim Watson (2008), China's carbon emissions and international trade: implications for post 2012 policy, Climate Policy 8: 577-587.

Weber, Nanne (2008), Kan men twee keer in dezelfde rivier stappen? Klimaatverandering door de tijd, oratie Universiteit Utrecht, 29 februari 2008.

Weishaar, Stefan (2008), The European Emissions Trading System: auctions and their challenges, in: M.G. Faure, M. Peeters (ed.) (2008), Climate Change and European Emissions Trading: Lessons for Theory and Practice.

Weitzman, Martin L. (2007), A Review of The Stern Review on the Economics of Climate Change, Journal of Economic Literature vol. XLV: 703-724.

Westra, Laura (2006), Environmental Justice and the Rights of Unborn and Future Generations, Earthscan. 
Whitesell, William (2007), Carbon taxes, cap-and-trade administration, and US legislation, Climate Policy 7: 457-462.

Wibisana, Andri (2008), Law and Economic Analysis of the Precautionary Principle, diss. Maastricht.

Wiener, Jonathan B. (2007), Think Globally, Act Globally: The Limits of Local Climate Policies, Duke Law School Legal Studies, Research Paper Series, Research Paper no. 158, May 2007.

Wiener, Jonathan B. (2008), Radiative Forcing: Climate Policy to Break the Logjam in Environmental Law, Duke Public Law \& Legal Theory Research Paper Series no. 225, November 2008.

Williams, Angela (2008), Turning the Tide: Recognizing Climate Change Refugees in International Law, Law \& Policy, vol. 3, no. 4.

Yanamin Farhana, Joanna Depledge (2004), The international climate change regime, Cambridge University Press.

Zinn, M. (2007), Adapting to Climate Change: Environmental Law in a Warmer World, in: Ecology Law Quarterly 34 (1): 61-106 


\section{Overige bronnen}

Bal, Elleke (2008), Socioloog: Klimaat nieuw bindmiddel voor Europa, NRC 8 mei 2008 (inzake lezing door socioloog Ulrich Beck aan de Universteit Maastricht).

Branson, Sir Richard, Keynote address, Addressing Climate Change, Thematic Debate United Nations General Assembly, http://www.un.org/ga/president/62/ThematicDebates/statements/ RichardBransonSpeech.shtml

Committee on Climate Change (2008), Interim advice by the Committee on Climate Change, 7 October 2008, CCC ref number: 001.

Commission of the European Communities (2001), European Governance, A White Paper, $\operatorname{COM}(2001) 428$ final, Brussels, 25.7.2001.

Commissie van de Europese Gemeenschappen (2008a), 25th Annual report from the Commission on monitoring the application of Community Law (2007), $\operatorname{COM}(2008) 777 / 4$..

Commissie van de Europese Gemeenschappen (2008b), Communication from the Commission to the European Parliament, the Council, The European Economic and Social Committee and the Committee of the regions on implementing European Community Environmental Law, Brussels COM(2008) 773/4.

Commissie van de Europese Gemeenschappen (2008c), Voorstel voor een Richtlijn van het Europees Parlement en de Raad tot wijziging van Richtlijn 2003/87/ EG teneinde de regeling voor de handel in broeikasgasemissierechten van de Gemeenschap te verbeteren en uit te breiden, KOM (2008) 16 definitief van 23.01.2008.

Commissie van de Europese Gemeenschappen (2008d), Voorstel voor een Richtlijn van het Europees Parlement en de Raad betreffende de geologische opslag van kooldioxide en tot wijziging van de Richtlijnen 85/337/EEG en 96/61/EG van de Raad, de Richtlijnen 2000/60/EG, 2001/80/EG, 2004/35/EG en 2006/12/EG en Verordening (EG) nr. 1013/2006, COM(2008) 18 definitief.

Commissie van de Europese Gemeenschappen (2008e), Directorate-General for Environment, Open Call for Proposals International Climate Change, juli 2008

Commissie van de Europese Gemeenschappen (2008f), Persbericht IP/O8/1909, Member States approve the phasing-out of incan-descent bulbs by 2012, Brussels, 8 December 2008.

Commissie van de Europese Gemeenschappen (2009), Citizens' summary EU climate and energy package, gepubliceerd op website http://ec.europa.eu/clima- 
teaction/docs/climate-energy_summary_en.pdf (bezocht 7 januari 2009).

Der Spiegel (2009), Cold Carbon Sink: Slowing Global Warming with Antarctic Iron, http://www.spiegel.de/international/world/o,1518,599213,0o.html

Europees Parlement (2008a): legislative resolution of 17 December 2008 on the proposal for a decision of the European Parliament and of the Council on the effort of Member States to reduce their greenhouse gas emissions to meet the Community's greenhouse gas emission reduction commitments up to 2020 (provisional edition).

Europees Parlement (2008b): legislative resolution of 17 December 2008 on the proposal for a directive of the European Parliament and of the Council amending Directive $2003 / 87 /$ EC so as to improve and extend the greenhouse gas emission allowance trading system of the Community (provisional edition).

Europees Parlement (2008c): legislative resolution of 17 December 2008 on the proposal for a directive of the European Parliament and of the Council on the geological storage of carbon dioxide and amending Council Directives 85/337/ EEC, 96/61/EC, Directives 2000/60/EC, 2001/80/EC, 2004/35/EC, 2006/12/EC and Regulation (EC) No 1013/2006 (provisional edition).

Europees Parlement (2008d): legislative resolution of 17 December 2008 on the proposal for a regulation of the European Parliament and of the Council setting emission performance standards for new passenger cars as part of the Community's integrated approach to reduce $\mathrm{CO}_{2}$ emissions from light-duty vehicles.

Europees Parlement (2008e): legislative resolution of 17 December 2008 on the proposal for a directive of the European Parliament and of the Council amending Directive $98 / 70 / E C$ as regards the specification of petrol, diesel and gas-oil and introducing a mechanism to monitor and reduce greenhouse gas emissions from the use of road transport fuels and amending Council Directive 1999/32/EC, as regards the specification of fuel used by inland waterway vessels and repealing Directive 93/12/EEC.

Lalieu, Elles (2008), Slimme schimmel maakt diesel, Change Magazine, http:// www.changemagazine.nl/artikelen/slimme_schimmel_maakt_diesel (13 november 2008).

Handhaving, Toezicht op emissies wordt volwassen, Handhaving 24e jaargang Oktober 2008, p22-25

House of Commons, The Environmental Audit Committee (2007), The Voluntary Carbon Offset Market, 3 July 2007. 
Malathouni, Elisa, Denise Prevost, Marjan Peeters (2009), An International Trade Law Perspective on Sectoral Greenhouse Gas Emission Mitigation Approaches (working paper).

Martens, Pim (2008), Klimaatdiscussie zonder oogkleppen, dagblad de Limburger / Knipselkrant Klimaatverandering jg 8 nr 14, 1 augustus 2008.

Milieudefensie (en andere maatschappelijke organisaties), (2008), Ontwerp voor een Klimaatwet, (http://www.klimaatwet.nu/downloads/ontwerp_wettekst. pdf), en de memorie van toelichting op dit voorstel (http://www.klimaatwet.nu/ downloads/toelichting_op_ontwerpwettekst.pdf), zie de website http://www. klimaatwet.nu/home,

Minewaterproject: http://www.minewaterproject.info/index.php.

Minister van Economische Zaken (2008), brief aan de Tweede Kamer, 29 oktober 2008, Kamerstuk II 31 209, nr. 43.

Minister van Volkshuisvesting, Ruimtelijke Ordening en Milieubeheer (2008) Brief van 24 september 2008, Kamerstukken II, 22 343, nr. 22.

Neerhof, Richard, Marjan Peeters (2008), Mijnwater en CO2-besparing: op zoek naar mogelijkheden voor verzilvering, contractonderzoek voor de Gemeente Heerlen, augustus 2008.

Nieuwsbrief Emissiehandel nr. 63, 23 december 2008.

Op 't Veld, Roy (2008), De strijd om energie, zoals vermeld in de Knipselkrant klimaatverandering, jg 8, nr. 10, 30-05-2008, p. 10.

Rees, William (2008), Keynote to the conference "Climate Law in Developing Countries post 2012: North and South Perspectives, September 26, 2008, IUCN Academy of Environmental Law, University of Ottawa, Canada (accessible through www.iucnael.org).

Robinson, Nicholas A. (2008), Melting Down Financial "Investment" Markets: Hedging Against Wider Collapse, Keynote Address 9th Global Conference on Environmental Taxation, National University of Singapore, 6 November 2008 (draft paper).

Sarkozy, M. Nicolas, Angela Merkel, Joint statement by M. Nicolas Sarkozy, President of the Republic, and Mrs Angela Merkel, Chancellor of Germany, on the climate, 9 Juni 2008,

http://www.ambafrance-uk.org/Franco-German-Council-of-Ministers,10729. html\#sommaire_2

Sectorakkoord Energie 2008-2020: Convenant tussen Rijksoverheid en energie- 
branches in het kader van het werkprogramma Schoon en Zuinig, 28 oktober 2008. Bijlage bij kamerstuk 31209, nr. 43, Tweede Kamer.

The New York Times, (1898) September 8, 1898: Nitrogen and Wheat, Prof.Crookes's address before the British Science Association.

United Nations Convention to Combat Desertification, Submission to the 4 th Session of the Ad Hoc Working Group on Long-term Cooperative Action under the Convention (AWG-LCA 4), Poznan, 1-10 December 2008, te vinden op http:// www.unccd.int/publicinfo/poznanclimatetalks/docs/Submission_by_UNCCD_ to_AWG-LCA_on_Biochar.pdf

UNFCCC (secretariat), Investment and financial flows to address climate change: an update,

Technical paper FCCC/TP/2008/7, 26 November 2008.

UNFCC, Kyoto Protocol, Enforcement branch of the Compliance Committee, CC-2007-1-8/Greece/EB, beslissing van 17 april 2008, http://unfccc.int/files/ kyoto_protocol/compliance/enforcement_branch/application/pdf/cc-2007-1-8_ greece_eb_final_decision.pdf.

Van Straaten, Floris (2008), We zullen opschuiven naar Russisch model, interview met Willem H. Buiter, Professor of European Political Economy, London School of Economics and Political Science, NRC 25 oktober 2008. 


\section{Jurisprudentie (inclusief administratief bezwaar / beroep)}

\section{Gerecht van Eerste Aanleg en Hof van Justitie EG}

Gerecht van Eerste Aanleg, T-374/04, Duitsland tegen Europese Commissie, (datum uitspraak 7 november 2007), Tijdschrift voor Milieu en Recht 2008 jur. nr. 12 met annotatie $M$. Peeters.

Gerecht van Eerste Aanleg, T-233/O4, Koninkrijk der Nederlanden versus Europese Commissie, (datum uitspraak 10 april 2008).

Hof van Justitie EG, C-127/07, prejudiciële beslissing in de procedure Société Arcelor Atlantique et Lorraine e.a. tegen Premier ministre, Ministre de l'Écologie et du Développement durable, Ministre de l'Économie, des Finances et de l'Industrie (datum uitspraak 16 december 2008).

\section{Nederland}

ABRvS 26 maart 2008, Tijdschrift voor Milieu en Recht, 2008, jur.nr. 60, met annotatie M. van Rijswick.

AB RvS 28 oktober 2008, 200707551/1, LJN: BG3360 (SITA Roosendaal).

\section{Verenigd Koninkrijk}

Judgment of the High Court of Justice, Queen's Bench Division, Adm inistrative Court, Case No: CO/3615/2007, date 10/10/2007 (mr Justice Burton).

\section{Verenigde Staten}

Supreme Court USA, Massachusetts v Environmental Protection Agency 549 U.S. 497 (2007) (uitspraak van 2 april 2007)

The Environmental Appeals Board, United States Environmental Protection Agency, Washington D.C., in re Deseret Power Electric Cooperative (November 13, 2008). 
